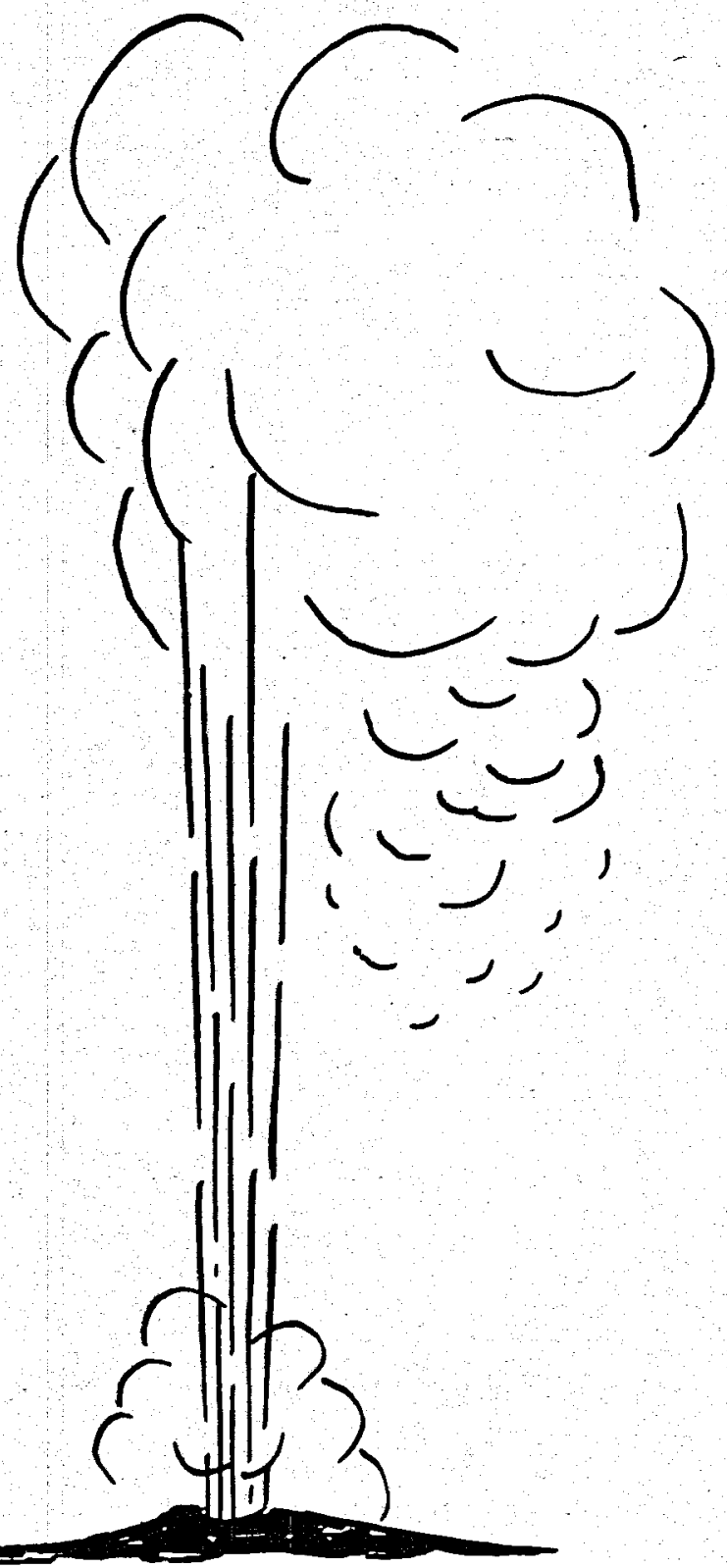

\title{
Guidelines to the Preparation of Environmental Reports for Geothermal Development Projects
}




\section{DISCLAIMER}

This report was prepared as an account of work sponsored by an agency of the United States Government. Neither the United States Government nor any agency Thereof, nor any of their employees, makes any warranty, express or implied, or assumes any legal liability or responsibility for the accuracy, completeness, or usefulness of any information, apparatus, product, or process disclosed, or represents that its use would not infringe privately owned rights. Reference herein to any specific commercial product, process, or service by trade name, trademark, manufacturer, or otherwise does not necessarily constitute or imply its endorsement, recommendation, or favoring by the United States Government or any agency thereof. The views and opinions of authors expressed herein do not necessarily state or reflect those of the United States Government or any agency thereof. 


\section{DISCLAIMER}

Portions of this document may be illegible in electronic image products. Images are produced from the best available original document. 
ERHQ-0001

UC $66 \mathrm{e}$

\section{GUIDELINES TO THE PREPARATION DF ENVIRONMENTAL REPORTS FOR GEOTHERMAL DEVELOPMENT PROJECTS}

U. S. Energy Research and Development Administration Division of Geothermal Energy 
1. PURPOSE OF THE GUIDELINES $\ldots \ldots \cdot \cdots \cdot \cdots \cdots$

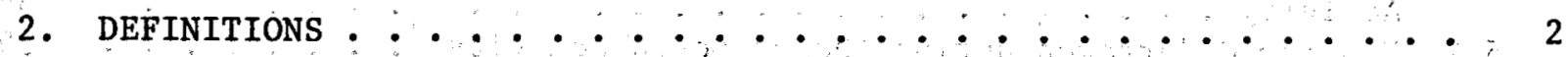

3. GENERAL INSTRUCTIONS ...................... 3

3.1 Scope . . . . . . . . . . . . . . . . 3

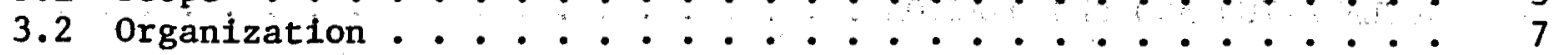

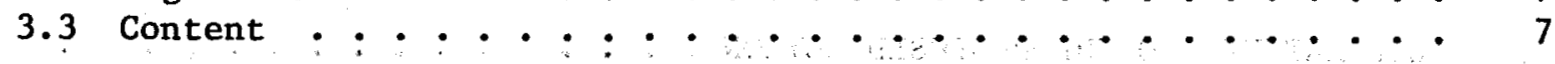

4. ERDA ACTION ON ENVIRONMENTAL REPORTS

5. FEDERAL LEGISLATION APPLICABLE TO GEOTHERMAL ACTIVITIES $\ldots \ldots$

6. STATE AND LOCAL ENVIRONMENTAL PROTECTION REQUIREMENTS $\ldots \ldots \ldots$

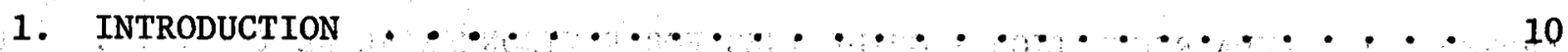

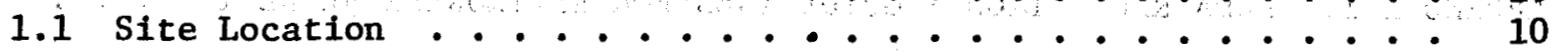

1.2 Activity objectives . . . . . . . . . . . . . . 10

1.3 Participants and Relationship to User

1.4 Relationship to the National Geothermal Development Program . . 10

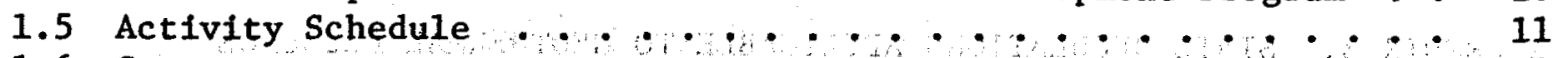

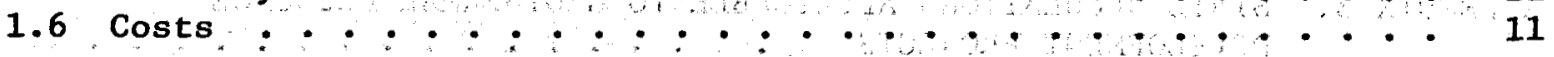

2. DESCRIPTION OF THE PROPOSED ACTIVITY . . . . . . . . . . . . 12

2.1 Systems Development . . . . . . . . . . . . . . . . 12

2.2 Resource Development . . . . . . . . . . . . . . . 12

2.3 Resource Utilization . . . . . . . . . . . . . 15

3. DESCRIPTION OF THE EXISTING SITE ENVIRONMENT . . . . . . . . . 20

3.1 Geography and Demography .. . . . . . . . . . . . . . 20

3.2 Land Use . . . . . . . . . . . . . . . . 22

3.3 Geology . . . . . . . . . . . . . . . . 22

3.4 Hydrology . . . . . . . . . . . . . . . . . 23

3.5 Meteorology . . . . . . . . . . . . . . . 24

3.6 Ecology . . . . . . . . . . . . . . . . . . 25

3.7 Regional Landmarks . . . . . . . . . . . . . . . 27

3.8 Social Profile . . . . . . . . . . . . . . . . 27 
CONTENTS

$\underline{\text { Page }}$

4. ENVIRONMENTAL EFFECTS OF THE PROPOSED ACTIVITY . . . . . . . . . . 29

4.1 Physical Environment . . . . . . . . . . . . . . . . 29

4.2 Ecological Environment . . . . . . . . . . . . . . . 30

4.3 Socioeconomic Environment . . . . . . . . . . . . . 32

4.4 Potential Accidents . . . . . . . . . . . . . . . 32

5. EFFLUENT AND ENVIRONMENTAL MEASUREMENT AND MONITORING PROGRAMS • • 34

5.1 Program Undertaken prior to the Start of the Proposed

Activity ....................... . . 34

5.2 Program Undertaken during the Proposed Activity . . . . . . . . 39

5.3 Other Environmental Measurement and Monitoring Programs . . . 39

6. RECLAMATION AND RESTORATION : . . . . . . . . . . . . . . 4 41

7. ALTERNATIVES TO THE PROPOSED ACTION . . . . . . . . . . . . . 42

8. IRREVERSIBLE AND IRRETRIEVABLE COMMITMENTS OF RESOURCES . . . . . 43

9. TRADE-OFF ANALYSIS . . . . . . . . . . . . . . . . . . 4 44

10. COMPLIANCE WITH REGULATIONS AND OTHER CONTROLS . . . . . . . . . . 45

APPENDICES

APPENDIX 1. ERDA REGULATION - GUIDELINES FOR ENVIRONMENTAL REVIEW • • 46

APPENDIX 2. FEDERAL REGULATIONS APPLICABLE TO GEOTHERMAL RESOURCE
DEVELOPMENT PROJECTS . . . . . . . . . . . . . . . . 54

APPENDIX 3. STATE REGULATIONS APPLICABLE TO GEOTHERMAL RESOURCE
DEVELOPMENT PROJECTS . . . . . . . . . . . . . . . 59 
CUIDELINES TO THE PREPARATION OF ENVIRONMENTAL REPORTS. FOR GEOTHERMAL DEVELOPMENT PROJECTS

PART A. INTRODUCTION

1. PURPOSE OF THE GUIDELINES

The National Environmenta1 Policy Act (NEPA) of 1969 (Public Law 91-190, 83 Stat. 852), implemented by Executive Order 11514 and the Council on Environmental Quality Guidelines of August 1, 1973, (38 FR 20550), requires that a11 agencies of the Federal Government prepare detailed environmental statements on proposals for legislation and other major federal actions significantly affecting the quality of the human environment. The principal objective of the National Environmental Policy Act is to build into the agency decisionmaking process an appropriate and careful consideration of environmental aspects of proposed actions.

The U. S. Energy Research and Development Administration (ERDA) through its Division of Geothermal Energy (DGE) is the federal agency responsible for certain actions that pertain to the development of geothermal resources. Such resources include (1) al1 products of geothermal processes, embracing indigenous steam, geopressured fluids, hot water, and brines; (2) steam and other gases, hot water and hot brines resulting from water, and natural gas or other fluids introduced into geothermal formations; (3) any by-products derived from geothermal resources, such as minerals or gases. By-products must either have a value less than $75 \%$ of the value of the geothermal resources from which they are derived or must not be of sufficient value alone to warrant extraction and production. In order to encourage the development of geothermal resources, ERDA conducts a program to assess those resources and to establish the technical, economic, and environmental acceptability of geothermal technologies. This program includes some proposed actions that could affect the environment.

As a means of obtaining information essential to satisfying the requirements of NEPA and its own regulations (10 CFR Part 711), ERDA requests that certain participants in the agency's programmatic activities submit an environmental report. The report describes the proposed programmatic activities and considers the potential impacts of those activities with respect to the existing environment. This guidelines document has been developed to provide assistance to participants in the preparation of environmental reports about geothermal activities.

The recommended organization and content of the environmental report are prescribed in this guide. The guide is intended to be comprehensive; a broad spectrum of geothermal activities is covered. Consequently, there are some activities for which parts of the guide are not applicable or for which less information than what is specified may be given. This guide instructs the 
user on how to scope the environmental report according to the scale of the proposed activity. When uncertainty exists the user should exercise prudent judgment about what constitutes an adequate level of reporting detail.

\section{DEFINITIONS}

As an aid to applying the guidelines set forth in this document, the definitions of some important terms are provided. These definitions are applicable solely in the context of this guide.

A geothermal "Environmental Impact Assessment" (EIA) is a written report prepared by the Division of Geothermal Energy. The EIA evaluates the environmental impacts of proposed geothermal activities to assure that environmental values are considered at the earliest possible time in the agency's decisionmaking process. The EIA is also used as a basis for determining whether or not an environmental impact statement should be prepared.

A geothermal "Environmental Impact Statement" (EIS) is a written statement prepared by ERDA. The EIS analyzes the anticipated environmental impacts of proposed geothermal activities and reasonable alternatives to those activities. The draft statement is written to satisfy NEPA requirements and, as such, is issued at the earliest possible time in the agency's decision-making process. The final statement reflects responsible public views and concerns regarding the proposed geothermal activities.

The "environmental report" is a written report submitted to the Division of Geothermal Energy by certain participants in ERDA's geothermal energy program. At a minimum the report contains the essential background material to assist ERDA in preparing an EIA or an EIS. This guide gives the specifications of content for that background material.

The "user" of this guide is any participant in ERDA's geothermal energy program who has intentions of undertaking geothermal and related activities that could affect the environment. Those participants expected to use this guide include (1) major ERDA contractors on geothermal energy research, development, and demonstration projects, (2) recipients of ERDA funds in partial support of geothermal energy projects, and (3) applicants for federal loan guarantees to conduct geothermal energy research, development, demonstration, or production on private or state-owned land (10 CFR Part 790). Some examples of users are: leaseholders, landowners, developers, utilities, industrial and commercial firms, research and development firms, and academic institutions.

A "proposed geothermal activity" is any project related to the production of geothermal energy for which funding or other support is sought from the Division of Geothermal Energy. If by their nature and locale such activities have the potential for directly impacting the environment, they will require at least the preparation of an EIA. Any other activity of the geothermal energy program which does not directly impact the environment generally will not require preparation of an EIA.

The "site" of a proposed geothermal activity is a parcel of land including surface water on which all or a major portion of the activity will be conducted. The site should have defined boundaries, and the user should have the right of 
access. Right of access is obtained through ownership of the site, by leaseholding, or with the written permission of the owner or lawful manager of the site. The site or some portion thereof may have previously been used for geothęrmal-related activities.

\section{GENERAL INSTRUCTIONS}

\subsection{SCOPE}

Geothermal activities or projects can be classified into three major categories: (1) Systems Development, (2) Resource Development, and (3) Resource Utilization. Activities concerned with Systems Development include projects to design, build, test, and operate new equipment or equipment systems that apply to some aspect of geothermal energy production. Development of a hightemperature logging tool would be an example of this category. The Resource Development category covers those activities normally associated with the extraction of geothermal energy from the ground. Well drilling and testing are examples of this category. Projects dealing with the ultimate uses of geothermal energy belong in the Resource Utilization category. The production of electric power from geothermal energy is an obvious example of an activity in this category.

Not all geothermal activities will necessitate the preparation of an environmental report. Table 1 lists those activities under each major category for which ERDA normally would request an environmental report. Note that the Resource Development category consists of three subcategories: Exploration, Production Testing, and Reservoir Development and Operation. The nature of these subcategories is evident from the activities listed.

The user should consult the table to verify that the proposed geothermal activity or any subactivity thereof is one of those covered by a report. A task to drill heat flow holes as part of an overall exploration project would be an example of a subactivity. If a project includes several subactivities for which environmental reports are requested, a single environmental report that covers those subactivities may be prepared. If there is, some question about the applicability of a particular activity or subactivity to the table, the user should consult with the Division of Geothermal Energy.

Upon determining under which category, if any, the proposed geothermal activity belongs, the user should determine which parts of this guide apply to that activity. Part B, standard Format and content, consists of specific instructions for preparing the ten chapters that may comprise an environmental report. These ten chapters are:

1. Introduction. A general summary description of the proposed activity and its relationship to the overall geothermal program.

2. Description of the Proposed Activity. A detailed presentation of those aspects of the activity that could affect the environment. 
Table 1. Geothermal Activities for which Environmental Reports Are Normally Prepared

\begin{tabular}{|c|c|c|}
\hline Systems Development & Resource Development & Resource Utilization \\
\hline $\begin{array}{l}\text { - Fabrication of equipment at } \\
\text { a test site } \\
\text { - Installation and testing of } \\
\text { geotherma } 1 \text { equipment at a } \\
\text { test site }\end{array}$ & $\begin{array}{l}\text { Exploration } \\
\text { - Geophysical surveys } \\
\text { - Shallow hole drilling } \\
\text { Production Testing } \\
\text { - Well drilling for } \\
\text { reservoir assessment } \\
\text { - Well flow testing } \\
\text { Reservoir Development and Operation } \\
\text { - Production well drilling for } \\
\text { geothermal energy extraction } \\
\text { - Injection well drilling } \\
\text { - Construction of collection and } \\
\text { disposal lines (piping) for } \\
\text { geothermal fluids } \\
\text { - Construction of temporary } \\
\text { facilities } \\
\text { - Supplying geothermal fluid for } \\
\text { resource utilization }\end{array}$ & $\begin{array}{l}\text { - Construction of permanent } \\
\text { facilities } \\
\text { - Electric power generation } \\
\text { - Space heating } \\
\text { - Agricultural applications } \\
\text { - Industrial applications } \\
\text { - Construction and operation } \\
\text { of special purpose test } \\
\text { facilities }\end{array}$ \\
\hline
\end{tabular}


3. Description of the Existing Environment. An accounting of the physical, biological, and socioeconomic characteristics of the environment that could be affected by the proposed activity.

4. Environmental Effects of the Proposed Activity. A discussion of the effects on the environment that could result from conducting the proposed activity.

5. Effluent and Environmental Measurement and Monitoring Programs. A description of environmental data collection programs done both prior to the proposed activity and planned during the activity.

6. Reclamation and Restoration. A description of planned efforts to reclaim and restore the site of the proposed activity.

7. Alternatives to the Proposed Action. A summary analysis of feasible alternatives to the proposed activity and their potential environmental effects.

8. Irreversible and Irretrievable Commitments of Resources. An identification of resources that are lost due to performance of the proposed activity.

9. Trade-0ff Analysis. An analysis which welghs the benefits of the proposed activity against the environmental costs (i.e., environmental impact) resulting from that activity.

10. Compliance with Regulations. A review of all environmental regulatory requirements that must be met to conduct the proposed activity.

The user should determine which chapters of the environmental report should be completed for the proposed geothermal activity. Table 2 is provided as an aid in this determination. The table is a matrix of the major activity categories versus the ten report chapters. The user should find the one column of the table which best fits the proposed geothermal activity. That column then specifies which chapters should be provided in the environmental report.

Some chapters of the report are optional; they may be included at the user's discretion. The table suggests only the minimum scope of the environmental report; the user can elect to provide information beyond the minimum shown in the table.

If a proposed activity includes subactivities from several categories (i.e., if more than one column of Table 2 can apply), the environmental report should contain every recommended chapter. As an example, an environmental report for a project that includes both exploration and production testing tasks should contain the chapters recommended for production testing. However, this does not preclude full and complete reporting of both tasks. 
Table 2. Recommended Contents of Environmental Reports on Proposed Geothermal Activites

\begin{tabular}{ccccccc}
\hline & Systems & \multicolumn{3}{c}{ Resource Development } & Resource \\
\cline { 3 - 5 } Chapter & Development & Exploration & Production & Testing & Reservoir D\&O & $\begin{array}{c}\text { Rtilization } \\
\text { Ution }\end{array}$ \\
\hline 1 & Yes & Yes & Yes & Yes & Yes \\
2 & Yes & Yes & Yes & Yes & Yes \\
3 & Yes & Yes & Yes & Yes & Yes \\
4 & Yes & Yes & Yes & Yes & Yes \\
5 & No & No & Yes & Yes & Yes \\
6 & No & Yes & Yes & Yes & Yes \\
7 & Yes & Yes & Yes & Yes & Yes \\
8 & No & No & Yes & Yes & Yes \\
9 & No & No & No & Yes & Yes \\
10 & Yes & Yes & Yes & Yes & Yes \\
\hline
\end{tabular}

aptiona1. 
The types and amounts of information to be reported under Chapters 2, 3 , and 5 depend upon the scale of the proposed activity. Additional instructions for scoping the information contents of Chapters 2, 3, and 5 are given in Part B of this guide.

\subsection{ORGANIZATION}

Part B identifies the specific information needed by ERDA for its analysis of the potential environmental effects of a proposed geothermal activity; this part gives an acceptable format for presenting that information and will aid in minimizing the time needed for the development of an EIA or EIS. The user is advised that this format is the one ERDA intends to use in preparing its own impact assessments and statements.

Conformance with the format is not required. An environmental report with a different format may be submitted if it provides an adequate basis from which ERDA can make an independent impact analysis. However, the user should understand that the review time for such a report may be longer and the likelihood that the report will be incomplete may be greater.

\subsection{CONTENT}

The suggested contents of environmental reports are summarized in Table 2, and detailed specifications for those contents are given in Part B.: As a rule the user should address the following considerations in developing an environmental report on any proposed geothermal activity:

(a) nature of the proposed action and the site of that action,

(b) the environmental impact of the proposed action,

(c) any adverse environmental effects which cannot be avoided should the proposal be implemented, and

(d) alternatives to the proposed action.

The environmental report should also include a discussion of the compliance of the proposed activity. with any environmental standards and requirements that apply.

The user should strive for a clear, concise presentation of information. Tables and charts, maps, line drawings, and photographs should be used wherever they contribute to the clarity and brevity of the report. The number of significant figures stated in numerical data should reflect the accuracy of that data.

Statements of fact should be supported by documentation. Besides the actual presentation of data as part of the report, documentation may include: (1) references to published information, (2) citations from the user's experience, and (3) references to unpublished information known to the user or 
developed by the user. The user should be prepared to provide ERDA with any referenced documentation not offered in the report.

Statements not supported by documentation are acceptable provided the user identifies them either as information for which documentation is unavailable or as expressions of belief or judgment.

Published information essential to evaluate specific environmental effects should be included in the environmental report. In particular, any previous environmental impact report, assessment, or statement covering the proposed activity or its site should be referenced and may be appended to the report. Information contained in such documents can be incorporated directly into the environmental report. However, that information must be current and useful to evaluate the effects of the proposed activity.

If the user considers any information requested by this guide to be a trade secret or confidential, that information should be clearly marked proprietary. The user should also submit a written request that ERDA withhold the information from public disclosure on the grounds that it is proprietary.

\section{ERDA ACTION ON ENVIRONMENTAL REPORTS}

The environmental report is the primary source of information ERDA will use in making an environmental impact analysis. Since ERDA is responsible for ensuring that its analysis is factual and comprehensive, the agency expects the environmental report and other data submitted by the user to be accurate and complete. If certain sections of the report need clarification, ERDA may request the user to submit additional information necessary to make an adequate assessment of the impacts under consideration.

In general, the impact analysis will be published in the form of either an EIA or EIS. The procedures for preparing and handling both an EIA and EIS are specified in the ERDA regulation, "Guidelines for Environmental Review" (10 CFR Part 711). This regulation is reproduced in Appendix 1.

The environmental impact analysis should be completed at the earliest possible time in ERDA's decision-making process. Therefore, the environmental report should be submitted no later than the time of the formal proposal to conduct the geothermal activity. Depending on the scope of the proposed activity, ERDA will require from three months to one year to perform its impact analysis. The user should make appropriate allowance for the impact analysis in scheduling the proposed activity's tasks. No task for which a potential environmental impact exists should begin before the analysis is completed.

\section{FEDERAL LEGISLATION APPLICABLE TO GEOTHERMAL ACTIVITIES}

In addition to the requirements of NEPA, there are a number of other environmental requirements that stem from federal legislation. The user is responsible for complying with those laws that apply to geothermal activities. As a convenience, a number of typically applicable federal laws are summarized in Appendix 2. 


\section{STATE AND LOCAL ENVIRONMENTAL PRO'TECTION REQUIREMENTS}

Though many states have enacted air and water quality control legislation, not all have enacted legislation specifically applying to the development and utilization of geothermal resources. A wide variation exists in the degree of complexity of state legislation and regulations pertaining both to environmental and geothermal activities. While some states have a formalized requirement for environmental impact reporting, other states have only a general reporting requirement. Local governments, like state governments, also show wide variation in their regulations pertaining to environmental effects and geothermal activities.

In addition to complying with federal environmental protection legislation, a geothermal participant must comply with state or local environmental protection laws or requirements. This is true even when the project is located on federally owned land. Federal regulations will prevail only in the event of a conflict between state and federal requirements.

A listing of typical laws and regulations applicable to geothermal development that have been promulgated by various states is presented in Appendix 3 . This listing should not necessarily be regarded as complete; the user must determine which regulations apply in the state or states where the proposed activity will take place. 
PART B: STANDARD FORMAT AND CONTENTS

\title{
1. INTRODUCTION
}

\begin{abstract}
The nature of the proposed activity and its relationship to the national geothermal development program should be briefly described in this chapter of the environmental report. The location, objectives, activity schedule, and costs of the project should be presented.
\end{abstract}

\subsection{SITE LOCATION}

The location of the proposed activity should be given to the nearest second of latitude and longitude and to the nearest 100 meters in Universal Transverse Mercator coordinates. The state, county, and other political subdivisions (e.g., town, township, city) in which the site is located should be identified. A small-scale map locating the site within the state should be included.

\subsection{ACTIVITY OBJECTIVES}

A description of the overall project, including the various implementation stages, should be given, and the objectives of the activity should be clearly stated. Intended uses of the site and geothermal reservoir should be described; consideration should not be limited only to those activities funded or sponsored by ERDA.

\subsection{PARTICIPANTS AND RELATIONSHIP TO USER}

All participants in the proposed activity should be identified and their relationship to ERDA, as well as to the user, should be clearly stated. When appropriate, distinction should be made among the owner of the geothermal field, the operator of the field, and the buyer or consumer of the recovered geothermal resource.

The user's experience in developing geothermal resources should be described. A general statement of the financing plan, including federal financing assistance (e.g., direct loans, grants, contracts) available or expected to be available in connection with the project, should also be included.

\subsection{RELATIONSHIP TO THE NATIONAL GEOTHERMAL DEVELOPMENT PROGRAM}

The ERDA program for geothermal energy research and development is focused both on the stimulation of industrial effort in providing the nation with electric 
power and non-electric energy (e.g., space heating and cooling, agriculture, food processing) and the development of technology for cost-effective and environmentally acceptable use of geothermal resources. A program developed by ERDA to achieve these goals--the National Geothermal Development Program--is described in the publication, "Geothermal Energy Research, Development and Demonstration Program" (ERDA-86). In this section of the environmental report the user should describe how the proposed project will help implement the goals and objectives of the ERDA program.

\subsection{ACTIVITY SCHEDULE}

A schedule should be provided which includes the starting date and expected duration of each phase or task of the proposed project. The planned start and completion dates for construction and operation of any geothermal wells and other facilities associated with the project should also be included.

\section{$1.6 \operatorname{cosTS}$}

The primary internal costs of the proposed activity should be summarized in this section. Consideration should be given to the following costs as app1icable:

(1) Capital costs of land acquisition and improvement;

(2) Capital costs of construction, such as

- Production and injection wells

- Drilling and casing

- Powerhouse and plant facility

- Waste heat dissipation system

(3) Operating and maintenance costs, including license fees, taxes, labor, and supervision;

(4) Facility decommissioning costs;

(5) Research and development costs;

(6) Exploration costs;

(7) Environmental measurement and monitoring costs. 


\title{
2. DESCRIPTION OF THE PROPOSED ACTIVITY
}

\begin{abstract}
All phases of the geothermal activity proposed by the user should be described. Included should be phases related to systems development, resource development, and resource utilization. The discussion should include both construction and operation portions of the proposed activity. Since environmental effects are of primary concern, the land requirements and effluents of the activity should be described in particular detail. Any pollution abatement systems and procedures incorporated as part of the proposed activity should also be described.
\end{abstract}

Only portions of this chapter will apply to any one proposed activity. The user can determine which sections should be completed by consulting Table 3 . This table gives the applicable sections for the major categories of proposed activities. If necessary, Table 1 in Part $A$ can be used to decide the category in which the proposed activity belongs.

\subsection{SYSTEMS DEVELOPMENT}

The proposed systems development activities should be discussed. Some examples of geothermal systems or components to which this section could apply are downhole pumps, heat exchangers, steam scrubbers, silencers, steam lines, and well casing. Only systems that are new, previously untested in the field, and not part of an overall resource production or utilization facility for the site qualify to be reported.

The description of the system should include (1) purpose, (2) concept design, (3) fabrication (e.g., resources consumed, facilities used), and (4) field testing (e.g., resources consumed, facilities used, effluents released, waste disposed of). Engineering drawings and flow diagrams should be employed, but only to the extent that they will clarify the system's operation and its potential for creating environmental impacts.

The user should note that only fabrication and field testing at the site require preparation of an environmental report; other systems development activities are exempt (see Table 1, Part A).

\subsection{RESOURCE DEVELOPMENT}

All proposed geothermal resource development activities should be described. Resource development activities have been divided into three phases: (a) exploration, (b) production testing, and (c) reservoir development and operation. The descriptive requirements for each are detailed below. 
Table 3. Applicable Sections of Chapter 2 for Major Activity Categories

\begin{tabular}{|c|c|c|c|c|}
\hline \multirow{2}{*}{$\begin{array}{l}\text { System } \\
\text { evelopment }\end{array}$} & \multicolumn{3}{|c|}{ Resource Development } & \multirow{2}{*}{$\begin{array}{l}\text { Resource } \\
\text { Utilization }\end{array}$} \\
\hline & Exploration & Production Testing & Reservoir D\&O & \\
\hline Yes & No & No & No & No \\
\hline No & Yes $(2.2 .1)$ & Yes $(2.2 .2)$ & Yes $(2.2 .3)$ & Yes (2.2.3) \\
\hline No & No & No & No & Yes \\
\hline
\end{tabular}




\subsubsection{Exploration}

The user should describe the proposed geothermal exploration program, the program strategy, schedule, and exploration tools and techniques to be employed. The activities to be covered include: (a) field surveys (e.g., active seismic); (b) shallow wells (e.g., heat flow and thermal gradient test holes).

The following information should be provided if it applies to the proposed activity:

(1) Locations of traverses, sampling points, existing and planned wells, access roads, and sources of water and road-building material.

(2) Drill pad preparation and layout.

(3) Planned off-road vehicle movements.

(4) Waste disposal methods. (Waste can include cuttings, drilling fluids, sewage, and trash.)

(5) Estimated land, water, utilities, fuel, manpower, and equipment requirements.

(6) Drilling, casing, cementation, and blowout prevention procedures.

(7) Sampling and analysis techniques (e.g., coring, logging) to be used in determining the properties of encountered geothermal resources.

(8) We11 abandonment procedures.

(9) Surface restoration procedures.

\subsubsection{Production Testing}

The user should present a discussion of the proposed geothermal production testing and related activities. Attention should be directed to the construction of roads, preparation of drill sites, drilling of test wells, testing of wells, disposal of solid and liquid wastes, and action to be taken regarding well abandonment and site restoration.

Descriptions should include:

(1) Locations of any existing wells and planned production well test sites, access roads, water supply and construction fill borrow areas.

(2) Drill pad preparation and layout.

(3) Planned off-road vehicle movements.

(4) Drilling, casing, cementation, and blowout prevention procedures.

(5) Estimated land, water, utilities, fuel, manpower, and equipment requirements.

(6) Flow testing equipment and procedures.

(7) Sampling and analysis techniques (e.g., coring, logging) to be used in determining the properties of encountered geothermal resources. 
(8) Identification of each gaseous and liquid effluent release source and the expected composition and quantity of effluents.

(9) Waste disposal methods. (Waste can include cuttings, drilling fluids, sewage, and trash.)

(10) Noise control methods.

(11) Well abandonment procedures.

(12) Surface restoration procedures.

\subsubsection{Reservo1r Development and Operation}

The proposed plan for developing the geothermal field should be addressed. This should include a description of the well field and a discussion of the composition and heat content of the available resource and the nature and extent of the reservolr and producing system as determined from the exploration and production testing programs.

Some typical information related to reservoir development includes: (1) 1ocations of production wells, roads, pipelines, injection wells, additional areas to be explored and/or tested, water supply, and support facilities; (2) production zones and rates, including well spacing, well stimulation methods, and rock fracturing techniques to increase permeability and maintain production rates; (3) road construction (both temporary and permanent); (4) dri11 pad preparation and layout; (5) production well drilling, casing, cementation, blowout prevention, and testing procedures; (6) estimated land, water, utilities, fuel, manpower, and equipment requirements; (7) composition and quantity of effluents; (8) noise control methods; (9) waste disposal methods; (10) surface restoration procedures.

Information describing the operation of the producing geothermal field should be provided if it differs from that supplied for reservolr development activities. Topics covered should include: (1) production well replacement scheduling; (2) wellhead components and steam-liquid separation equipment; (3) location and capacity of injection wells; (4) pipeline systems; (5) composition, quantity, and source locations of effluent releases (venting and well purging); (6) well and pipeline maintenance; (7) well plugging and abandonment; (8) estimated land, water, utilities, fuel, manpower, and equipment requirements; (9) waste disposal methods; (10) surface restoration procedures.

\subsection{RESOURCE UTILIZATION}

The user should describe the proposed utilization system or process, especially the planned construction and operation activities. Construction activities to be described in this section are those associated only with the utilization system and related subsystems identified in this section.

\subsubsection{Construction}

The user's environmental report should cover the expected construction activities and required equipment, manpower, and resources, both onsite and offsite. 
Environmental effects are the primary concern of the report, hence al1 construction activity associated with the proposed facilities and related systems (e.g., access roads, transmission lines, distributive pipelines) that will inevitably affect the environment should be addressed.

The discussion of site preparation work and facilities construction should be organized in terms of land use and water use. The discussion of land use should describe construction activities and identify specific land areas to be involved. A large-scale map would probably aid the discussion. The use of land in connection with such tasks as creating material supply areas, building temporary or permanent roads, bridges, and service lines, disposing of trash and chemical wastes (including oil), excavating, clearing vegetation, and land filling should be described. Information bearing on such issues as extent and duration of land disturbance, atmospheric emissions, and use of explosives should be provided to the extent necessary to serve as a basis for discussion of impacts in later chapters. Sources of noise and expected movements of men and material should be identified. An annual schedule of the estimated work force to be involved in site preparation and facilities construction should be presented.

The expected use of water for various construction activities should be identified and quantified, and the sources of water supply and methods of withdrawal should be specified. Activities that have the potential for impacting water (groundwater or surface water) should be identified and described. The overall plan for protection of water bodies from the effects of construction should be discussed. Actions that might affect water use include: the construction of reservoirs, cofferdams, and waste retention ponds; dredging operations; placement of fill material in the water; diking; drainage diversion; erecting shoreside facilities such as piers and jetties; building intake and discharge structures; straightening or deepening of water channels; any other operations affecting water levels (either surface or groundwater).

If the proposed activity is generation of electric power, plans, for clearing of rights-of-way and construction of transmission facilities also should be discussed. The following items should serve as guidelines for the discussion, but the user may include any additional relevant material:

(1) Identify proposed transmission line routes through use of contour maps and/or aerial photographs; also show substation locations and other points at which the proposed transmission system will connect with the existing high-voltage system. Specify the lengths, widths, and total area covered by proposed rights-of-way.

(2) State the proposed techniques for clearing the rights-of-way, especially any plans for use of growth retardants, chemicals, biocides, etc., during construction and installation of the lines.

(3) Indicate the methods to be used in erecting the transmission line structures and stringing conductors.

(4) Indicate the number and length of new access and service roads required.

(5) Indicate any plans for removal of man-made structures.

(6) Identify any areas where the transmission lines will be placed underground. 
(7) Indicate where highways, railways, water bodies, and areas of archeological, historical, and recreational interest will be crossed.

(8) Indicate where transmission lines offer potential hazard to aerial navigation, and reference appropriate FAA standards.

\section{3 .2 Operation}

The operation of the proposed resource utilization project, as well as related or support systems, should be addressed in this section. Varfous types of utilization projects are identified below, each accompanied by a list of specific items that should be considered. In addition to these specific requirements, the user should provide a discussion of items common to any utilization project:

(1) External Appearance--The layout of buildings and the facility's perimeter should be illustrated and shown on a site map. The facility's profile relative to its surroundings should be shown in perspective by color drawings or other illustrative techniques; a graphic representation of the facility should be included.

(2) Water Use--A schematic water-use diagram showing values of maximum and average water flows to and from the various facility systems (e.g., heat dissipation system, chemical waste system, process water system, support systems) should be presented; geothermal fluids should be excluded. The sources of the water for each system should be described, and values of maximum and average annual consumptive use from each should be given. The amount of water used under various operational conditions should be tabulated. Such conditions can include expected and design rates of operation, temporary shutdown, and operation without various support systems. If onsite reservoirs are to be created as needed components of the project, their design capacities and expected fluctuations of water level should be given.

(3) Gaseous Effluents--Probable gaseous effluent release points (e.g., stack, exhaust, vent) should be identified, and the location and elevation of each should be clearly shown on appropriate diagrams. All sources of effluents should be identified. Care should be taken to distinguish effluents whose source is geothermal fluid from effluents derived from other sources, such as diesel exhaust. The nature and composition of the effluents and the design and operation of any control systems should be described. The user should provide estimates of release rates and the total amounts released annually for the various gaseous effluents from each release point. In particular, estimates of the amounts of $\mathrm{CO}_{2}, \mathrm{H}_{2} \mathrm{~S}, \mathrm{NH}_{3}, \mathrm{CH}_{4}, \mathrm{SO}_{2}, \mathrm{NO}_{\mathrm{x}}$, boron, mercury, radon, and particulates released annually from various sources should be presented. The pathways of release from source to release point should be indicated. Airborne concentrations of gaseous effluents and areal deposition rates for chemicals and solids entrained in spray fallout should be estimated. The methods and bases for any estimates should be explained.

(4) Liquid and Solid Waste Disposal--The liquid and solid waste disposal systems (e.g., process, chemical, sanitary) should be described. The adequacy of the systems to process wastes generated during normal operation and abnormal occurrences should be considered. Quantities of wastes from all identified sources should be estimated. Provisions for storage, transfer, and final disposition of wastes, including geothermal waters, should be described, and locations of all release points should be indicated on the facility layout. 
Normal and expected maximum discharges of chemical additives (e.g., corrosion inhibitors, chemical and biological antifouling agents, cleaning compounds), corrosion products, waste streams or discharges from drains, and other released liquids that may enter the local environment as a result of the facility's operation should be listed. Maximum and average concentrations of chemicals and solids in any brines or cooling system effluents should be given. The user should be careful to distinguish the geothermal fluid disposal system from other waste disposal systems.

(5) Support Systems--The user should identify other facility-related systems not previously covered. Their function and operation, particularly any effluents produced, should be described.

(6) Personnel Requirements--A schedule of normal and maximum personnel requirements during expected operating conditions should be provided.

(7) Maintenance and Outages--The provisions for operational maintenance of all primary and support systems, whether on or off the site, should be summarized. The frequency and duration of outages should be estimated, and procedures to be followed during planned outages and during emergency or unplanned outages should be outlined.

(8) Noise Control--The means of handling noise resulting from normal operation of the utilization project should be described.

The following sections provide requirements for specific information in regard to particular utilization projects. These items of information are to be provided in addition to, but not distinct from, the general information called for above.

Electric Power Generation. The type of turbine generator, manufacturer, and number of units should be stated. Rated and design input and output levels of the turbine generators, as well as inplant power consumption, should be given. The use of secondary or binary heat exchanger systems should be described if applicable.

The waste heat dissipation system should be discussed in detail. Process flow diagrams and scale drawings of intake and outfall structures (if required) should be presented. The reasons for providing the particular system, such as water supply limitations, should be noted. The source of the cooling water should be identified. Topics to be covered include: quantity of heat dissipated; design, size, and location of cooling towers, cooling lakes, or spray ponds; air and water flow rates; estimates of drift from cooling towers; blowdown volume, rate of discharge, and physical and chemical characteristics of towers and ponds; temperature changes, rate of changes, and holdup times in cooling ponds or artificial lakes; cooling range; intake and outfall design, including discharge velocity and the depth of the discharge structure in the receiving water. Any seasonal variations in operating characteristics should be noted.

Transmission lines and related facilities (e.g., substations) that are to be constructed between the proposed plant and interconnecting points on the existing high-voltage transmission system should be described. Description of the proposed transmission system should include such basic design factors as voltage, capacity under normal and emergency load conditions, conductor type and configuration, tower heights and spans, and minimum height of the 
conductor above the ground. Illustrations or profile drawings of conductors and structures should be provided. The dimensions, materials, color, and finish of the towers should be specified. The user should estimate levels of radiated electrical and acoustic noise, ground level potential gradients, Induced or conducted ground currents, and ozone production resulting from operation of the proposed transmission system.

Space Heating. Sumary descriptions should be provided for the following: (a) the overall utilization system, (b) the distribution network (and return network, if applicable), (c) pumping stations (Including pumps and their ratings), and (d) heat exchange system at utilization points. Diagrams and maps showing locations of facilities, along with line drawings and specifications of components and equipment, should be provided.

Agricultural Applications. The general utilization scheme and system operation should be described and illustrated with suitable diagrams. The distribution network, pumping stations, and heat exchangers also should be described.

Special Purpose Testing. Any facility whose intended function ts to serve as a laboratory for the testing of geothermal reservoirs or equipment systems qualifies as a special purpose test facility. The testing program of such a facility could apply to a wide range of equipment, from individual components to whole, integrated systems. In fact, the entire facility could be the subject of the testing. The user should note the distinction between a proposed activity to build and operate a special purpose test facility and one to test equipment at such a facility. This section of the guide applies to the former activity, whereas Section 2.1 applies to the latter.

The user should describe the operational aspects of the facility, the range of testing applications, the heat dissipation system, and the effluent control systems.

Multipurpose Applications. In those cases where two or more types of utilization schemes will be employed, descriptions of all schemes should be provided to the level of detail specified for each by this guide.

If the proposed utilization activities are not covered by those previously listed, the user should take the above as examples of pertinent information to describe the activity. 


\section{DESCRIPTION OF THE EXISTING SITE ENVIRONMENT}

This chapter of the environmental report should present basic information relevant to those physical, biological, demographic, and socioeconomic characteristics of the environment that might reasonably be expected to be affected by the proposed activity. To the extent possible, the information presented should reflect observations and measurements made over a period of years.

This chapter of the guide contains a comprehensive summary of information needed to fully characterize the site environment. However, the detail to which the environment is reported should match the degree of environmental impact that could result from the proposed activity. The level of detail can also be governed by the site location, the size, and the type of activity. The user should decide what constitutes an adequate description of the site environment for analyzing potential environmental impacts.

Portions of this chapter do not apply to certain categories of proposed activities. The user can determine which sections should be completed by consulting Table 4. If necessary, Table 1 of Part A can be used to categorize the proposed activity.

\subsection{GEOGRAPHY AND DEMOGRAPHY}

\subsubsection{Site P1an}

A topographic map of the site area of suitable scale (with explanatory text as necessary) should be included and should clearly show the following:

1. The site boundary and the area of the site in acres or square meters;

2. Nature and orientation of existing and planned geothermal structures within or adjacent to the site area. Geothermal structures can include steam lines, turbine building, cooling towers, switchyard, and geothermal wells;

3. Any other industrial, recreational, or residential structures within or adjacent to the site;

4. A scale which will permit accurate measurement of distances;

5. True north;

6. Highways, railways, and waterways that traverse or are adjacent to the site; 
Table 4. Applicable Sections of Chapter 3 for Major Activity Categories

\begin{tabular}{|c|c|c|c|c|c|}
\hline \multirow[b]{2}{*}{ Section } & \multirow{2}{*}{$\begin{array}{c}\text { System } \\
\text { Development }\end{array}$} & \multicolumn{3}{|c|}{ Resource Development } & \multirow{2}{*}{$\begin{array}{l}\text { Resource } \\
\text { Utilization }\end{array}$} \\
\hline & & Exploration & Production Testing & Reservoir D\&O & \\
\hline 3.1 & $\operatorname{Yes}^{\mathrm{a}}$ & Yes $^{a}$ & Yes $^{a}$ & Yes & Yes \\
\hline 3.2 & No & No & Yes $^{a}$ & Yes & Yes \\
\hline 3.3 & No & Yes $^{a}$ & Yes & Yes & Yes \\
\hline 3.4 & No & No & Yes $^{a}$ & Yes $^{a}$ & Yes \\
\hline 3.5 & No & No & Yes $^{a}$ & Yes $^{a}$ & Yes \\
\hline 3.6 & Yes $^{a}$ & Yes $^{a}$ & Yes $^{a}$ & Yes & Yes \\
\hline 3.7 & No & Yes $^{a}$ & Yes $^{a}$ & Yes & Yes \\
\hline $3.8=$ & Yes $^{a}$ & Yes $^{a}$ & Yes & Yes & Yes \\
\hline
\end{tabular}

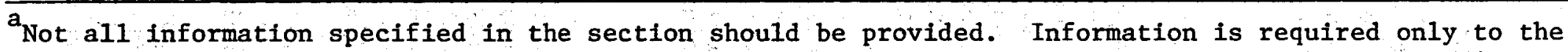
extent that it contributes to the understanding of an environmental impact reported in Chapter 4. 
7. Principal man-made and natural features such as rivers and lakes within or adjacent to the site boundary.

\subsubsection{Regiona1 Demography}

A large-scale map showing inhabited areas and population centers within a tenmile radius of the site should be provided. A table keyed to the map should list the most recent census data on residential population. Any other population centers likely to be affected by the proposed activity should be similarly described. Permanent and transient populations should be distinguished by describing seasonal and daily variations in population size and distribution. resulting from the use of recreational and industrial facilities.

\subsection{LAND USE}

The characteristics of the surrounding terrain and the general use of land in the area should be summarized. Dedicated land use types, such as agricultural areas, residences, settlements, commercial areas, industrial plants, parks, wildlife refuges, public forests, recreational lands, and transportation systems should be shown on a topographic map. That part of the site to be occupied or modified by the proposed activity should be indicated. Any other existing or proposed land uses in the site area should be identified. The user should specify any zoning restrictions on or near the site. A zoning map may be useful for this purpose.

The information should be organized so as to demonstrate coordination of the proposed activity with various uses of land outside the site. As required, the discussion should include offsite access corridors, such as the rights-ofway for cooling water conveyance, new roadways, and other features that relate to the principal purpose of the activity.

\subsection{GEOLOGY}

The user should present a geologic map of the region. The discussion accompanying the map should cover stratigraphy, structure, faulting, and tectonic history. The regional continuity, faulting, and strike and dip of waterbearing formations that may be affected by the proposed activity should be briefly noted. Known mineral and energy resources that are of regional economic importance should be identified. Any other known geothermal resource areas in the region should be listed.

The user should discuss the seismic history of te region, and when possible, associate seismic events with tectonic features. A regional earthquake epicenter and tectonic map that includes the site should be provided.

The geology of the site should be addressed; the age, type, and structure of strata at the site should be reported. The discussion of site geology should include the suspected origin and nature of the geothermal resource. A vertical cross section may be used to illustrate the geology. 
The user should pay particular attention to hazardous geologic phenomena that have affected the site. Such phenomena may include flooding, landslides, mudslides, faulting, earthquakes, and volcanism. The amounts and rates of contemporary uplift and/or subsidence should be estimated.

The natural radioactivity at the site should be reported in this section. Radium and radon are the two elements of special interest. If the background level differs from that expected for the region, the probable cause of the difference should be identified.

\subsection{HYDROLOGY}

The effects of the proposed activity on adjacent surface and groundwaters are of prime importance. The user should describe, in quantitative terms if possible, the physical, chemical, and hydrological characteristics of the waters, their typical seasonal ranges and averages, and their historical lows and highs.

\section{$3,4.1$ Surface Water}

The features of local and regional surface waters should be described. The hydrologic properties (e.g., temperature, flow rate, stage or water level, currents), basin morphology (e.g., drainage areas, tributaries, channel or shoreline character), chemical characteristics, and water quality should be provided. If possible, the user should give the source, concentration range, and chemical species of any pollutants now present in nearby surface waters, and discuss any time variations in their release. Data on hydrologic properties should include measurements made on or proximate to the site. Water lost by evaporation, drawdown, percolation, or evapotranspiration should be estimated. The user should give the observed or estimated 7-day, 10-year low flow for the site's major source of surface water. Additionally, information should be given on the period-of-record drought flow sequence, transposed to the site.

\subsubsection{Groundwater}

Groundwater aquifers, formations, and recharge areas in the vicinity of the site should be identified. Included should be summaries of groundwater table elevation (including seasonal variations and gradients) and water quality. Any association of groundwater aquifers with the geothermal reservoir should be discussed in detail.

The location of freshwater aquifers (i.e., less than $10,000 \mathrm{mg} / 1 \mathrm{TDS}$ ) should be indicated with respect to any proposed waste ponds and other impoundments, sanitary landfills, and sewage disposal facilities. Waste disposal wells in the vicinity of the site should be identified. Information should be given concerning the hydraulic properties (e.g., permeability and porosity) of materials between these sources of waste and the freshwater aquifers. 


\subsubsection{Water Use}

The proposed geothermal activity can affect the water use patterns in the region of the project site, and conversely, water availability can impose limitations on the activity. The following topics should be addressed by the user to provide a comprehensive picture of regional water use.

The environmental report should identify the location, nature, and amounts of present and projected surface and groundwater use in the region, including use for agriculture, domestic water supplies, recreation, industrial consumption, and transportation. The location of major water users should be shown on maps that identify separate intake and discharge points.

The user should review the prevailing constraints on water availability imposed by treaty, compact, court decree, state law, and water rights granted pursuant to state or federa1 laws.

\subsection{METEOROLOGY}

The user should provide site-specific meteorological data or data applicable to the general site area as reported by the National Weather Service or other authoritative sources. In general, the meteorological information must be appropriate to be used as the basis for estimating the impact of atmospheric emissions. In particular, the atmospheric dispersion properties of the project site should be characterized.

The following data on site meteorology should be provided: (a) diurnal and monthly averages and extremes of temperature, dewpoint, and humidity; (b) monthly wind characteristics (i.e., speeds, directions, and joint frequencies of wind speed, stability category, and wind direction), and those heights at which winds have been measured; (c) monthly and annual average precipitation; (d) frequency of occurrence and effects of storms accompanied by high velocity winds. Under item (b), the joint wind speed-stability-direction frequencies should be given as fractions when using five-year National Weather Service summaries or as the number of occurrences when using only one or two years of onsite data. The data should be tabulated for each of the 16 cardinal compass directions, and the stability categories should be established to conform as closely as possible to those of Pasquill.

The environmental report should also include a discussion of local and regional climatology, existing levels of air pollution from geothermal and non-geothermal sources, the relationships of the meteorological data gathered onsite to that gathered on a regional basis, and the impact of the local terrain and large lakes and other bodies of water on meteorological conditions in the area.

If the use of a wet, dry, or wet-dry cooling tower is proposed, the user should furnish appropriate summaries of joint humidity data, along with the joint wind speed, stability category, and wind direction frequencies for heights related to the cooling tower dispersion regime. These summaries should be based on data collected over a period of at least six months in order to provide the basis for estimating the impact of tower operation on the 
environment. If the user does not have the detailed site-specific meteorological data described above, information from the general area gathered by the National Weather Service or other authoritative sources may be substituted.

\subsection{ECOLOGY}

\subsubsection{Terrestrial}

This section should include discussions of the soils, flora, and fauna that characterize the terrestrial environment of the site, any access and transmission corridors, and adjacent areas. The consideration of peripheral areas should be limited to that necessary to establish the general nature of the local ecology. In addition, ecological relationships within and among the various components of the terrestrial systems should be identified.

Information on soils should include the identification, distribution, and characteristics of major soil groupings (i.e., soil associations) occurring at the site. More detailed information may be needed in some instances. The production potential of soils should also be indicated by U. S. Department of Agriculture soil capability classes or equivalent indices. Field reconnaissance may be necessary, but published literature and information from the U. S. Soil Conservation Service will usually be adequate.

Plant communities should be identified and described in terms of structure, composition and successional status; a map of their distribution should be prepared. The discussion should be supported by a reasonably complete inventory of floral and faunal species characteristic of the communities in the project area. Information concerning relative abundance and distribution of such species should also be reported. Field surveys, published literature, and interviews with knowledgeable specialists should provide an adequate basis for identifying important species. A plant or animal species is classed as "important" if a potentially adverse relationship between the species and the proposed geothermal activity can be identified, and if one or more of the following criteria are applicable:

1. The species is endangered or threatened with endangerment.

2. The species is commercially or recreationally valuable.

3. The species critically affects the welfare of species identified by criteria 1 or 2 above.

4. The species is critical to the structure or function of the ecological system.

5. The species is a biological indicator of toxic conditions in the environment.

In the case of important species, information concerning abundance, distribution, life histories, and habitat requirements should be provided.

Inventoried plant species should be catalogued as trees, shrubs and herbaceous or ground flora. Normally, the lower plants--mosses and terrestrial 
algae--would not be inventoried. However, if any such species is considered important and may be adversely affected by project activities, the appropriate information should be provided.

The inventory of fauna should include the principal domestic species, as well as wildlife. The inventoried species should be catalogued as mammals, birds, reptiles, amphibians, and invertebrates. Normally, only the more abundant and "important" invertebrates should be included in the inventory. Field surveys should be of sufficient duration to detect the onsite presence of migratory or other species which are observable only during certain seasons.

Characterization of communities should include discussions of relationships between major components of terrestrial ecosystems (e.g., soil-plant and plant-animal interactions). Additional considerations of ecological phenomena should include, but not be limited to, food chains, predator-prey relationships, disease vectors, and prevailing environmental stresses, including human activities. Special consideration should be given to determining the concentrations of potentially toxic substances in soils and biota of areas which may be influenced by the proposed activity.

\subsubsection{Aquatic}

This section should include discussions of aquatic habitats, and of the characteristic plant and animal groups of each habitat. Offsite aquatic systems associated with the site should be included in the discussion. Interrelationships of the aquatic environments should also be identified.

The description of the aquatic environment requires additional information on abiotic parameters beyond that presented in Section 3.6.1. This includes a description of the physical limnology and a physical and chemical characterization of the sediments for all aquatic systems on the site. Aquatic habitats, such as lakes, rivers, springs, and wetlands, should be identified, described, and mapped.

Communities of aquatic flora and fauna (e.g., benthos, plankton, fish, and macrophytes) should be described. General information concerning the relative abundance and distribution of species should be reported. Important species should be identified in accordance with procedures and criteria outlined in Section 3.6.1. Detailed information concerning abundance, life histories, and habitat requirements of important species should be reported. This discussion should include a reasonably complete inventory of the aquatic organisms of the communities described.

A discussion of community relationships should be presented which parallels that outlined in Section 3.6.1. In addition, seasonal changes in the major biotic and abiotic components of each community should be discussed. Unique and scientifically valuable thermal ecosystems are frequently associated with geothermal areas; the user should locate and describe any such ecosystems. 


\subsubsection{Endangered Species and Habitats}

The report should include a summary of the status of plant and animal species determined to be endangered or threatened with respect to the site. Critical habitats of such species, as well as the manner in wich such habitats are utilized (e.g., nesting, breeding, feeding) by the species, should be identified. Federal (Public Law 93-205,87, Stat. 884 and regulations and amendments thereto), state, and other official listings of environmentally stressed species should also be consulted.

\subsection{REGIONAL LANDMARKS}

The proposed activity may affect reglonal landmarks valued for their historic, scenic, archeological, architectural, or natural features. The environmental report should discuss the value or significance of any features on or near the site as regional landmarks. Specific attention should be given to the sites and areas listed in the "National Register of Historic Places" and the "National Registry of Natural Landmarks." Both 1ists appear in the Federal Register. Further guidance can be obtained from the National Park Service publication, "Preparation of Environmental Statements: Guidelines for Discussion of Cultural (Historic, Archeological, Architectural) Resources," August 1973.*

Also, the user should consult with the appropriate state liaison officer for historic preservation about properties under consideration for nomination to the "National Register of Historic Places" and summarize such consultations in the environmental report. The environmental report also should contain evidence of contact with the Historic Preservation Officer or equivalent authority for the state involved. The report should include a copy of the officer's written comments concerning the effect of the undertaking on historic, archeological, and cultural resources. Procedures for the protection of historic and cultural properties were published in the Federal Register (39 FR 3366) on January 25, 1974.

The user should indicate whether the site has any archeological significance, and how this conclusion was reached. If features of significance or value are present, the user should describe any preservational plans filed with a public agency.

\subsection{SOCIAL PROFILE}

This section should address those community characteristics and esthetic, recreational, and cultural values that can be affected by the proposed activity. The community is the population of both permanent and temporary residents likely to be affected. In the absence of a well-defined community, the total population within a ten-mile radius of the site may be substituted.

*Copies may be obtained from Chief Historian, Room 1226, National Park

Service, 18th and C Streets, N.W., Washington, D. C. 20240. 


\subsubsection{Community Characteristics}

The user should characterize the social structure of the community in terms of (1) age and sex distribution of residents; (2) urban, suburban and rural areas, (3) local governments and institutions; (4) the economic structure in terms of total income and output, income groups and income distribution, tax revenues and base; (5) employment trends; and (6) community services such as health care, education, police and fire protection, water treatment, sewage disposal, garbage collection, public transit, and welfare.

\subsubsection{Esthetic, Recreational and Cultural Values}

Community facilities such as parks, artificial lakes, and marinas having regional esthetic, recreational, or cultural value should be identified and described. The scenic quality of the site and its surroundings should be discussed.

\subsubsection{Ambient Noise}

Any measurements of ambient noise levels within and adjacent to the site should be reported. Particular attention should be paid nearby populated areas that could be affected by noise caused by the proposed activity. Data on noise levels should be representative of existing conditions throughout the area. 


\title{
4. ENVIRONMENTAL EFFECTS OF THE PROPOSED ACTIVITY
}

\begin{abstract}
In this chapter of the environmental report the user should discuss the effects that could result if the activities described in chapter 2 are undertaken. The effects should be discussed in terms of their physical impacts on the resources and populations described in Chapter 3. The discussion should be confined to those residual effects that remain after mitigative measures have been employed as part of the proposed activity. Environmental effects that are considered unavoidable but either inherently temporary or amenable to relief should be clearly distinguished from those regarded as unavoidable and irreversible.
\end{abstract}

The impacts of instituting the proposed activity should be quantified to the extent practicable and should be systematically presented. In discussing each impact, the user should make clear whether the supporting evidence is based on theoretical, laboratory, onsite, or field studies, and whether these studies were conducted specifically for the activity or for some other reason. The source of each impact and the population or resource affected should be made clear in each case.

Impacts should be distinguished in terms of their effects on individual components of the environment. The report should also identify those components for which no impact is expected.

Finally, the user should discuss the relationship between local short-term uses of the environment and the maintenance and enhancement of 1ong-term productivity. As used in this guide, "short term" may be taken to refer to the life of the proposed activity and "long term" to time periods extending beyond this life. The user should assess the activity for cumulative and projected long-term effects from the point of view that each generation is trustee of the environment for each succeeding generation. This means considering, for example, the commitment of a water source as a cooling medium in terms of impairment of other actual or potential uses.

\subsection{PHYSICAL ENVIRONMENT}

Any effects, beneficial or adverse, on the various components of the physical environment resulting from implementation of the proposed activity should be presented in this section.

\subsubsection{Land Use}

Expected impacts on the terrain and on existing and projected land use should be described. Estimates of the amount of land to be affected and the nature 
and duration of the impact should be included. The discussion should address not only such topics as the effects of construction and operation of major facilities on land use, but also surface subsidence resulting from the withdrawal of geothermal fluids, disposal of trash and wastes generated by drilling operations, and any other project-related actions resulting in impacts on land use, either on or off the site.

\subsubsection{Water Use}

The effects of water consumption on competing demands (e.g., irrigation, municipal water supplies) for local and regional water resources should be described. The user should submit evidence--in the form of official documents from the appropriate agency or copies of contracts with owners of existing water rights-of his possession of water rights to support his plans to withdraw and use water from public water supplies. The user should demonstrate that the project will be in conformance with existing restrictions on water use.

\subsubsection{Water Quality}

Impacts on surface or underground water quality resulting from the release of wastes should be estimated and compared both to ambient conditions and to any applicable local, state, or federal regulations or guidelines. The consequences of such water quality impacts should also be addressed.

\subsubsection{Natural Resources}

A discussion of any effects on exploration or production of mineral or energy resources as a result of implementation of the proposed activity should be included.

\subsubsection{Air Quality}

The user should discuss the effects of the proposed activity on the atmosphere. Particular attention should be given to noncondensible gaseous effluents. However, the effects of heat, water vapor, and particulate matter should also be considered.

\subsection{ECOLOGICAL ENVIRONMENT}

This section should include discussion of the areal extent, manner, and intensity to which terrestrial and aquatic environments will be affected by the proposed activity.

\subsubsection{Terrestrial}

The acreages and kinds of soils destroyed or altered during construction work should be quantified; the effects on productivity and erosion potential should be discussed. The kinds and areal extent of plant communities destroyed or 
altered by mechanical, chemical, or other methods should be tabulated; if chemicals are used for clearing vegetation, the kinds of herbicides or silvicides should be specified and the dosage rates, method of application, and number of applications noted.

Consideration of wildlife should include species affected and losses of food resources, protective cover, den sites, and breeding, nesting, and nursery areas. The kinds and numbers of animals destroyed or displaced by construction should be predicted, and the impact of displaced anima1s on adjacent biotic communities discussed. Interference with the daily or seasonal movements of species should be considered, if appropriate. Expected and potential effects on endangered or otherwise important species should be emphasized.

Any environmental impacts resulting from disposal of construction wastes, dust production, and routine or accidental introduction of potentially toxic materials into the local environment should be discussed.

The user should discuss the impacts of pollutants on the adjacent terrestrial biota. This discussion should include, wind and water transport of brine evaporite to adjacent areas. Particular attention should be given to substances with the potential to do significant blological harm. Effects on particularly sensitive species should be considered. Consideration also should be given to bioaccumulation (i.e,, concentration in food chains), if appropriate.

The user should examine the ecological impacts caused by the disposal andor storage of geothermal fluids, if applicable. The user should also consider the ecological consequences of any subsidence resulting from the extraction of geothermal fluids.

The formation of ice and changes in microclimate due to water vapor emitted by geothermal facilities may affect the local biota. The occurrence and the effects of these phenomena should be examined if the user determines a reasonable potential exists.

\section{2 .2 Aquatic}

The direct and indirect effects of construction should be discussed in terms of aquatic organisms and habitat altered or destroyed. The discussion should include the effects of sediment loading and the possibility of water quality changes resulting from surface runoff and/or contamination of groundwater. The effects of potentially toxic materials used in, or related to, construction should be identified. The degree to which the facility structures or construction activities may interfere with daily or seasonal movements of aquatic organisms should be discussed, if appropriate. If the construction activities result in a net increase in the temperature of surface waters, the effect on biota, especially cold-water species, should be evaluated.

In instances where water is withdrawn from surface water bodies, the user should discuss impingement and entrainment of organisms due to that withdrawal. Measures to minimize impingement and entrainment should be described.

Liquid effluents channeled to a receiving water body should be discussed in terms of volumes, thermal properties, and chemical concentrations; these 
parameters should be related to the optimum and tolerance limits of important species and food base organisms. Scouring and sediment production at the outfall should also be considered. The consideration of effects on aquatic biota should not be limited to the mixing zone, because the entire receiving water body (and interconnected aquatic systems) may be affected. The discussion should include such factors as changes in the natural circulation patterns, water quality, and alterations in nutrient budgets of the receiving water.

Deposition of airborne pollutants may also contribute to the impacts on aquatic systems. The potential for ingestion and bioaccumulation of toxic materials in food chains should be reported.

Exploitation of geothermal resources may result in a disturbance of natural thermal features such as hot springs. The user should indicate the potential effects on the unique ecosystems associated with such features.

\subsection{SOCIOECONOMIC ENVIRONMENT}

The user should address both favorable and adverse effects on the socioeconomic environment. Modifications of community characteristics should be described in terms of changes in life styles, social structures, and population.

Impacts on economic structure should be discussed. Some factors for which impacts should be considered are: (1) changes in total community income and output: (2) income distribution; (3) the emergence of income groups; (4) incremental increase in regional products; (5) changes in local and state tax revenues and structures.

Impacts on employment through the creation of new and temporary jobs and resulting increases in demands for community factlities and services should be addressed. Probable changes in regional esthetic, recreational, and cultural values should be reported. Inconveniences in the form of increased noise levels, traffic congestion, and pollution should be identified and quantified. The user should provide an assessment of the visual impacts of the proposed activity on cultural, scenic, historic, and recreational areas. The assessment should include drawings or modified photographs showing any facilities associated with the proposed activity and their surroundings as visible from these nearby vantage points. The number of people that would be affected by such visual intrusions should be estimated.

The user should state whether any offsite right-of-way will pass through or near an area of known historic, scenic, cultural, natural, or archeological significance.

\subsection{POTENTIAL ACCIDENTS}

Accidents are short-term phenomena that present a danger to human health and safety and environmental well being; they are usually caused by human error or the failure of a vital piece of equipment. Some types of accidents that might occur as a result of geothermal activities include well blowout, explosion, fire, spillage of pollutants or hazardous material, and leakage of wells, holding ponds, or sumps. 
The user should discuss the full range of credible potential accidents that could occur during the implementation of the proposed activity. The discussions should include the expected cause(s) and consequence of each potential accident. Preventive and remedial measures for accidents should also be presented. 


\title{
5. EFFLUENT AND ENVIRONMENTAL MEASUREMENT AND MONITORING PROGRAMS
}

\begin{abstract}
In this chapter the user should describe the procedures for collection of the baseline data presented in other chapters and discuss any plans or programs for environmental monitoring to detect impacts of the proposed activity.
\end{abstract}

This chapter is not required for those activities that belong to the Systems Development or Exploration categories; it is optional for activities classified as Production Testing (see Table 2 in Part A). However, if there are measurement or monitoring programs for a proposed activity from one of these categories, the user is encouraged to report them. Environmental reports for all other activities should contain a description of relevant measurement and monitoring programs. In each case the user should supply information only to the extent that it is pertinent to environmental characterization and environmental effects described in Chapters 3 and 4.

\subsection{PROGRAM UNDERTAKEN PRIOR TO THE START OF THE PROPOSED ACTIVITY}

This section should describe the program for characterizing the site and the surrounding region (including any rights-of-way related to the project) prior to the start of the proposed activity. The guide indicates general environmental factors to be evaluated and the parameters to be measured; the user should add any other factors necessary to provide reasonably complete baseline data against which to measure future impacts. Excellent guidance for developing an environmental measurements program is given in "Guidelines for Acquiring Environmental Baseline Data on Federal Geothermal Leases" (The Geothermal Environmental Advisory Pane1, January 1977).*

The program for collection of initial or baseline environmental data prior to initiating the proposed activity should be described in sufficient detail to demonstrate that the user has established a thorough and comprehensive approach to data collection. The description of the program should be confined principally to technical descriptions of instrumentation, scheduling, technique and procedures.

Particular attention should be paid to the description of sampling design, sampling frequency, statistical methodology and validity (including calibration checks and standards) in order to justify the scope of the program and the timing and scheduling of data collection. Information should be provided on instrument accuracy, sensitivity and reliability. When standard analytical or sampling techniques are to be utilized, they need only be identified and referenced.

*Copies may be obtained from the Chairman, Geothermal Environmental Advisory Panel, 345 Middlefield Road, Menlo Park, CA 94025. 
When information from the literature has been used, it should be concisely summarized and documented by reference to original data sources. When the availability of original sources that support important conclusions is limited, either extensive quotations or references to secondary sources should be provided. In all cases, information derived from published results should be clearly distinguished from information derived from the user's field measurements.

\subsubsection{Surface Waters}

When a body of surface water may be affected by the proposed activity, the report should describe the means by which the baseline conditions of the water and the related ecology were determined. Sufficient data should be gathered to permit verification of any predictive computations or models used in the evaluation of environmental effects.

The methods for measuring physical and chemical parameters of surface waters should be described. The user's sampling program should be outlined in sufficient detail to demonstrate 1 ts adequacy with respect to both spatial coverage (i.e., surface area and depth) and temporal coverage (i.e., duration and sampling frequency), giving due consideration to seasonal effects. The techniques used to investigate any condition that might lead to interactions with effluents (such as how the presence of impurities in a water body may react synergistically with heated effluent or how the heated effluent may restrict mixing and dispersion of pollutants) should be described.

Table 5 lists the important chemical species occasionally found in spent geothermal fluids. The physical properties of water likely to be affected by any geothermal effluent discharges are also 1isted. The monitoring program need not include all of these parameters but should cover those that are expected to significantly impair the quality of surface waters. Other important parameters not listed should be reported if unusual ambient conditions warrant their inclusion.

The report should describe any computational models used in predicting spatial and temporal changes in surface water quality and the dispersion characteristics of surface waters. The discussion should include the bases for these models, the means for their verffication, and their validity and accuracy.

The user should describe the baseline program used to characterize aquatic systems in the project area. Details concerning the rationale, techniques, and equipment used for ecological assessments should be included. All sampling programs should be discussed in terms of the pattern and frequency of sampling and duration of observations, with emphasis on those procedures used to estab1ish the presence and abundance of important species.

The methods of analysis and interpretations of field and laboratory data should be discussed. This discussion should include degrees of precision and accuracy of reported estimates when appropriate. Procedures for verification of taxonomic determinations should be discussed, either by reference to a collection of voucher specimens or other means whereby consistent identification of species is assured. 
Table 5. Water Quality Parameters Associated

With Geothermal Effluents

\section{Chemical Parameters}

$\begin{array}{lll}\mathrm{Ag} & \mathrm{F} & \mathrm{NH}_{4}^{+} \\ \mathrm{As} & \mathrm{Fe} & \mathrm{Pb} \\ \mathrm{B} \mathrm{as} \mathrm{H}_{3} \mathrm{BO}_{3} & \mathrm{HCO}_{3}^{-} & \mathrm{Rb} \\ \mathrm{Ba} & \mathrm{Hg} & \mathrm{Si} \text { as } \mathrm{SiO}_{2} \\ \mathrm{Br} & \mathrm{H}_{2} \mathrm{~S} & \mathrm{SO}_{4} \\ \mathrm{Ca} & \mathrm{I} & \mathrm{Zn} \\ \mathrm{CH}_{4} & \mathrm{~K} & \text { Alkalinity, acidity and } \mathrm{pH} \\ \mathrm{Cl}^{-} & \mathrm{Li} & \text { Total dissolved solids } \\ \mathrm{CO}_{2} & \mathrm{Mg} & \text { Dissolved oxygen } \\ \mathrm{Cs} & \mathrm{Mn} & \text { BOD and COD } \\ \mathrm{Cu} & \mathrm{Na} & \text { Radioactivity }\end{array}$

Physica1 Parameters

Color

Suspended solids

Taste and odor

Temperature

Turbidity

Atmospheric reaeration rate

Evaporation rate

Velocity (average) 
Rationale for predictions of any nonlethal physiological or behavioral responses of important species due to project-related impacts should be discussed. Parameters of stress for important species of the aquatic systems should be identified, including potential synergistic effects.

\section{1 .2 Groundwater}

The monitoring program for detection of impacts on local groundwater should be described.

Required information concerning the properties and configuration of the local aquifers, spatial and temporal variations in groundwater levels and groundwater quality data should have been presented in sufficient detail in Chapter 3 to permit a reasonable projection of the effects of the proposed activity on groundwater. Methods (including instrumentation) used to obtain and reduce the data presented should be described. The monitoring program should include those chemical species and characteristics listed in Table 5 that are expected to significantly impair the quality of groundwater.

Models may be used to predict such effects as changes in groundwater levels, dispersion of contaminants, and eventual transport through aquifers to surface water bodies or wells.: The models should be described and supporting evidence for their reliability and validity presented.

\section{1 .3 Air}

The user should describe the programs for obtaining information on local air quality, if relevant, and local meteorology. The report should address particularly those materials that are known to be present in the geothermal fluid or steam, especially as non-condensable gases. Air pollutants of possible geothermal origin are listed in Table 6 ; the air monitoring program should include those that can significantly impair the local air quality. The sampling, location, instrumentation, frequency, and duration of measurement should be specified.

Table 6. Potential Air Pollutants Associated with Geothermal Steam

\begin{tabular}{ll}
\hline $\mathrm{CH}_{4}$ & $\mathrm{H}_{2} \mathrm{~S}$ \\
$\mathrm{C}_{2} \mathrm{H}_{6}$ & $\mathrm{Hg}$ \\
$\mathrm{CO}_{2}$ & $\mathrm{~N}_{2}$ \\
$\mathrm{H}_{2}$ & $\mathrm{NH}_{3}$ \\
$\mathrm{H}_{2} \mathrm{BO}_{3}$ & Rn and daughter products \\
$\mathrm{HF}$ & Aerosols \\
$\mathrm{H}_{2} \mathrm{O}$ & Particulates \\
$\mathrm{H}_{3} \mathrm{PO}_{4}$ & \\
\hline
\end{tabular}


The user should identify sources of meteorological data used in atmospheric transport models. Locations and elevations of observation stations and frequency and duration of measurements should, be specified both for the user's measuring activities and for activities of governmental agencies or other organizations on whose information the user has relied. The report should include descriptions of instruments, performance specifications, calibration and maintenance procedures, data output and recording systems and locations, and data analysis procedures.

Any models used to estimate basic meteorological information or to estimate the effects of effluent systems should be described in detail and their validity and accuracy discussed.

\section{1 .4 Land}

The collection and evaluation of data regarding the terrestrial environment should be presented.

Those geological studies designed to determine the environmental impact of the proposed activity should be described, including the sampling pattern, the sampling methods, pre-analysis treatment, and analytic techniques. In particular, any vertical leveling surveys or other land deformation studies associated with monitoring subsidence should be reported. Any efforts to monitor seismic activity in the vicinity of the site should also be reported.

The report should state the methods used for identifying the actual land use in the site environs and for acquiring demographic data for the region. Sources of information should be listed, and methods used to forecast probable changes in land use and demographic trends should be described.

Studies designed to determine the physical and chemical properties of soils should also be described. Descriptions should include: (1) soil parameters assessed; (2) the rationale for, and identification of, the sampling pattern; (3) the sampling methods; (4) pre-analysis treatment of samples; and (5) analytical techniques utilized. Statistical treatments of soil properties should include estimates of standard error, if appropriate. Methods used for determining natural variations of soil parameters should be reported. The rationale for utilizing available data for predicting impacts should be described.

Methods and techniques implemented to inventory the biota and assess ecological relationships should be discussed, especially with reference to important terrestrial biota. The general considerations for sampling and analysis should be similar to those suggested for aquatic systems (Sec. 5.1.1). However, the design and timing of surveys would necessarily vary to accommodate differences in (1) physical habitat, (2) character and habits of terrestrial biota, and (3) interrelationships of terrestrial systems. The user should present, as in Section 5.1.1, the details of the program used for taxonomic validation, as well as the rationale and details of methodologies used for predictive assessments. 


\subsection{PROGRAM UNDERTAKEN DURING THE PROPOSED ACTIVITY}

This section of the environmental report should cover the scope and objectives of the monitoring program to be undertaken during the proposed activity. The treatment should be similar to that outlined in Section 5.1. Details on differences between the programs prior to and during the proposed activity in terms of technique, instrumentation, scheduling, and procedures, as well as reasons for such differences, should be provided. A tentative listing of parameters to be monitored for detailed evaluation should be provided. Excerpts from applicable water and air quality standards should be included, and these standards should serve as limits for normal operating conditions.

In addition to monitoring surface water, groundwater, air, land, and ecology, the proposed program for monitoring gaseous and liquid effluents both from geothermal and non-geothermal sources should be explained in terms of:

(1) methods, locations, and frequencies of sampling; (2) analytical techniques;

(3) instrumentation sensitivity and reliability. Monitoring procedures prescribed by local, state, or federal agencies as conditions placed upon operation should be identified.

The criteria for setting threshold levels for corrective action should be presented. In the case of prescribed quantitative standards set by agencies, the applicable regulation should be cited. For quantitative limits set by the user to conform to qualitative standards or restrictions, the user's rationale should be presented. In either case, the user should specify the action to be taken if measurements exceed thresholds.

In principle, the baseline measurement program (Section 5.1) established by the user should be appropriate for monitoring effects on aquatic ecological systems during the proposed activity. However, the user may choose to modify the overall monitoring effort. Certain monitoring may serve no further purpose with respect to the project. In other instances, the program may be made more effective by changing frequency of sampling, locations of sampling stations, and so forth. Any changes should be described and justified. If possible, the user should indicate how changes in the physlological and behavioral characteristics of aquatic biota may be attributed to specific effects of plant operation, to natural variation, or to other causes.

The previous guidance with respect to monitoring of aquatic systems is genera1ly applicable to terrestrial systems.

\subsection{OTHER ENVIRONMENTAL MEASUREMENT AND MONITORING PROGRAMS}

Other environmental measurement and monitoring programs in the vicinity of the site may be conducted by organizations not directly supported by the user. If these programs are relevant to characterize the site environment or monitor the proposed activity, they may be substituted for portions of the user's measurement and monitoring programs.

The report should identify those organizations responsible for other environmental measurement and monitoring programs. The procedures and methods used to conduct these other programs should be summarized. The user should defend the 
relevance and adequacy of any programs that are offered as substitutes for elements of the user's programs. The user's plan to acquire and integrate information from other environmental programs should be presented. 


\section{RECLAMATION AND RESTORATION}

In this chapter the user should describe plans and policies regarding reclamation and restoration of the site at the end of the proposed activity's useful life.

Topics that should be addressed include well field abandonment; amount of land irretrievably committed; amount of equipment and buildings to be removed; specific actions to be initiated for reclamation or restoration of disturbed areas; environmental consequences of reclamation and restoration activities; state and local requirements, such as bonding to ensure adequate restoration; and estimated costs of abandonment and of restoration. 


\section{ALTERNATIVES TO THE PROPOSED ACTIVITY}

This chapter of the environmental report should present a descriptive analysis of the alternatives available within the scope of the activity. It should include information relevant both to the availability of alternatives and to their relative merits. The chapter should also present the basis for the user's selection of the proposed activity from among the available options.

The discussion of alternatives should be confined to options such as siting within a lease area, use of the geothermal resource, and facility and equipment designs. Alternatives should be of a site- and resource-specific nature. The report should demonstrate that the proposed site-activity combination is clearly preferable over the other alternatives both from engineering and environmental impact standpoints.

The discussion should include consideration of alternatives for support facilities as well. For example, alternative transmission line routes and terminal locations should be considered. The rationale for the selection of the proposed routes should be discussed. Sufficient information (including selection criteria) for assessment of the alternative routes should be provided.

Throughout this chapter the user should emphasize those alternatives that appear promising in terms of environmental protection. Different designs for processes and facilities that are essentially identical with respect to environmental effects should be considered only if their costs are appreciably different. Alternatives should be included if (1) they provide improved levels of environmental protection, and (2) although not necessarily economically attractive, they are based on feasible technology available to the user.

Discussions of potential environmental effects of alternatives should be documented and supported by available information. To the extent practicable, the magnitude of each effect should be estimated. Where quantification is not possible, qualitative evaluations should be expressed in terms of comparison to the effects of the proposed activity. 


\title{
8. IRREVERSIBLE AND IRRETRIEVABLE COMMTTMENTS OF RESOURCES
}

\begin{abstract}
Any irreversible and irretrievable commitments of resources expected to result from any phase of the geothermal activity should be discussed. This discussion should include both direct commitments, such as depletion of thermal energy and water from a geothermal reservoir, and irreversible environmental losses, such as land subsidence and deposition of heavy metals into surrounding soils. All resources, including water, land, mineral, biotic, energy, and societal, should be considered.
\end{abstract}

In this discussion, resource losses (e.g., land, water, fuel, nonrecyclable building materials) should be considered in terms of relative, long-term net, and absolute effects. As an example of relative impact assessment, the loss of a few individuals of a given animal or plant species could represent different degrees of significance, depending on the total population in the immediate region. In the case of a small local population, such a loss could be less serfous if the same species were abundant in neighboring regions. Similarly, the loss of a given amount of highly desirable land should be evaluated in terms of the total amount of such land in the environs. These relative assessments should show the percentage of expected resource loss in relation to that existing in surrounding regions. The same approach, or other applicable methods, should be applied in assessing irreversible and irretrievable commitments of other resources impacted by or utilized in conjunction with the proposed activity. The discussion should include both direct commitments, such as depletion of geothermal resources, and irreversible environmental losses, such as consumptive use of water. 


\section{TRADE-OFF ANALYSIS}

This chapter of the environmental report should demonstrate, through a trade-off analysis of the impacts of the proposed activity, why in the user's judgment the aggregate benefits outweigh the aggregate costs.

Although the trade-off analysis approach is conceptually similar to the benefitcost approach classically employed in a purely economic context, the methods differ procedurally. This is because the impacts to be evaluated will not all be monetized by the user. The incommensurable nature of some impacts makes it virtually impossible to provide a concise assessment of benefits vs. costs in quantitative terms. Even though a simple numerical weighing of benefits against costs is clearly not feasible here, the user can evaluate the impacts on a judgmental basis that is consistent with the underlying concept of benefitcost analysis.

As indicated above, it is incumbent on the user to demonstrate that the benefits of the proposed activity are considered to outweigh the aggregate costs. In presenting the trade-off analysis, the user should first consider the benefits from the proposed activity. Second, project expenditures and environmental impacts should be considered; these debits should be summarized in tabular form.

Activities of a "research and development" nature typically have costs that far exceed their immediate benefits. However, the user should be able to show that the eventual benefits from such activities will compensate for any immediate costs. 
10. COMPLIANCE WITH REGULATIONS AND OTHER CONTROLS

In this chapter the user should list all federal, state, and regional licenses, permits, and approvals; environmental quality requirements, laws, and ordinances; land use plans, policies, and controls applicable to the proposed activity.

A list and description of all relevant land use plans (or zoning restrictions), policies, rules, and regulations of all federal, state, and local regulatory agencies as they affect the site of the proposed activity should be provided. The user should also discuss fully how his proposed activity may conform or conflict with the objectives and specific terms of these approved or proposed land use plans, policies, and controls. In the event full reconciliation cannot be achieved, the user should state the extent to which the proposed activity has been reconciled with the plan, policy, or control.

The user should list and give the status of all licenses, permits, and other approvals of construction and operations required by federal, state, local, and regional authorities for the protection of the environment. The relevant statutory or other authority requiring approvals with respect to construction and/or operation should be cited. The list should be categorized by the environmental component to which the approval is addressed; categories could include, for example, air, land, and water use and planning. The listing should contain any environmental quality requirements, laws, and ordinances applicable to the proposed activity. A comparison of legal limits or standards with conditions expected to result from implementation of the proposed activity should be made.

If applicable, the status of efforts to obtain a water quality certification under Section 401 and discharge permits under Section 402 of the Federal Water Pollution Control Act (FWPCA), as amended, should be summarized. Any other actions, such as a pending request based on Section 316(a) of FWPCA for alternative effluent limitations, should be explained.

If a discharge could alter the quality of the water or air of another state, the user should indicate the state or states that may be affected and their applicable limitations, standards, or regulations.

Where consumptive water uses involve permits, the user should show evidence of such with respect to state, federal, or other authorities having purview over the proposed diversion.

The user should also report all contacts and consultations made with state, local, and regional regulatory authorities. Any meeting held with environmental and other citizen groups should be cited. 
APPENDIX 1.

ERDA REGULATION - GUIDELINES

FOR ENVIRONMENTAL REVIEW 


\section{CHAPTER III-U.8. ENEACY RESEARCH \\ PART 711-GUIDEUNES FOR ENVIRONMENTAL REVIEW Misceltaneous Amendments}

On February 14, 1874, suidelines were promilgated and published in the FroIRAL REGISTER (39 FR 6620) entablishing poltcles and procedures for the discharge of the responsiblitiles of the Atomic Energy Commission (AEC) -operations with respect to the National Environmental Pollcy Act of 1969 (NEPA) and other related authorities. The Energy Research and Development Administration (ERDA), the statutory successor to the operational functions of the AEC as a result of the Energy Reorganization Act of 1974, adopted those guidelines on March 3, 1975 (40 FR 8794). The purpose of those regulations was explained in the preamble to the AEC operations guidepream

Experience with these guidelines has indicated that certain changes are needed for the sake of clarity, particularly in amending the guldelines to conform to ERDA's organizational structure. Accordingly, Part 711 of Title 10, Code of Federal Regulations is amended as set forth below.

These amendments. will apply to all units of ERDA. They will apply to all reviews of proposed actions not yet commenced and will also apply to the maximum extent practicable to reviews currently in process. These amendments are promulgated as final amendments to the guidelines since they are matters relating to agency procedures and the agency destres that these procedures be avallable immediately for application to the large number of environmental reviews currently in process. For these reasons, the agency has determined that it is not necessary to provide notice of propased rulemaking, opportunity for public parttcipation or delay of effective date. However, in order to provide the public with an opportunity to comment on these guideines, interested persons may submit, on or before March 14, 1977, written comments to the Director, Offlce of NEPA Coordination, Mail Station E-201. U.S Energy Research and Development Administration, Washington, D.C. 20545. These comments will be considered with respect to the desirability of further amendment of this Part.

These amendments are promulgated under authority provided in Section 105 88 Stat. 1238 (42 USC 5815), and section 102, 83 Stat. 853 (42 USC 4332) and are effective January 26, 1977. Part 711 is hereby revised to read as follows.

Dated at Germantown. Maryland, this 8 th day of December 1976.

For the Energy Research and Develop. ment Administration.

JAMES L. LTVERMas: Assistant Administrator. for Environment and Safety.

711.1 Background

7112 Purpose.

7113 Pollcy.

711.5 Applicabillty
Subpart Q-Environmentat Impact Ascossments 711.23 Criteris for determming need tor Impset assessments.

71126 Content of environmental impect Beo. assessmonts.

711.27. Eubmiadon of epvironmental Impsct essesaments.

711.29 Replew of environmental impact ssressments.

711.31 Negative deciarations.

Subpst C-Environmantal Impact statements

711.41 Criterla for determining need for environmental impact, atatements.

711.43 scope of environmental impact itatements.

711.45 Timing of environmental impact ilatemente.

711.47 Responsibllities for preparation of environmental impsct statements.

711.49 Notice of intent

711.51 , Required lists.

71d.53 Submission and review of draft environmental impact atatements.

711.55 Public hearlngs.

711.57 Preparation, reviow and distribution of Ansl enptronmental impact itatements.

711.63 Timing for proposed ERDA dctions.

711.67 Amendments or supplements to nngl environmental Impact statements.

711.69 Review of other apencles' environmental impact statements.

Subpart D Eeneral Guldance tor Content of

711.81 Cover.

711.83 Body of otatement.

Authontry: Bec. 105, 88 stat. 1238 (42 U.S.C. 5813 ); Bec. 102, 83 Btat. 853 (49 U.S.C. 4332).

\section{Subpart A-General}

\subsection{Background.}

(a) The National Environmental Policy Act of 1869 (NERPA), Implemented by Executive Order 11514 (F.O. 11514) dated March 5, 1970 (85 FR 4247), and the Guidelines of the Councll on in vironmental Quality (CEQ) of August 1 1973 (40 CFR Fart 1500, 38 ITR 20550) require that all agencles of the Federal Government prepare detalled environmental statements on proposals for legislation and other major Federal actions significantly affecting the quality of the human environment. The objec tive of NEPA is to build into the Federal agency decisionmaking process, beginning at the earliest possible point, an appropriate and careful consideration of environmental aspects of proposed ac tions in order that adverse environmental effects may be avoided or minimized. In addition, section 309 of the Clean Air Act (CAA), as amended, provides that the Administrator of the Environmental Protection Agency (EPA) shall review and comment on any matter relating to EPA's authority contained in such proposed legislation or such other major Federal action. Office of Management and Budget (OMB) Bulletin No 72-6 of September 14, 1871, and OMB Circula No. A-95 (Revised) of January 2, 1976 provide guidance in connection with the evaluation, review and coordination of Federal projects and activities

\section{$\$ 711.2$ Purmose.}

(a) This Part establishes policy and procedure for discharging the Energy Research and Development Administration's (GRDA) responsibllities with respect to NEPA. E.O. 11514, section 309 of the CAA, OMB Bullettn No, 72-6, OMB Circular 2No. A-85 (Revlsed) and the CEQ Gutdelines, as they may be emended from time to time. This Part wlll be reviewed and revised, in consultation with CDQ, to onsure full compliance with these directives. This Part, is intended to provide culdance for:

(1), Identifying the agency environmental appratsal process, those BRDA actions requiring environmental impact assessments and-statements and the time schedule for appropriate particlpation prior to agency decision of applicable Federal, Btate and local governmental units and members of the public:

(2) Obtaining informatton to allow the potential environmental impact of administrative and legislative actlons to recelve full consideration in the agency decisionmaking process;

(3) Obtaining information and internal ERDA review required for the preparation of environmental impact assessments and statements:

(4) Designating the ERDA officials who are to be responsible for preparation, review and approval of environmental impact assessments and statements.

8711.3 Policy.

(a) Consistent with BRDA's statutory responsibilities and other essential considerations of national policy, ERDA shall conduct Its activities in $u$ manner calculated to promote the general welfare, to encourage productive and enjoyable harmony between man and his environment, to minimlee damage to the environment, to enhance environmental quality, to restore environmental quality lost previously, and to preserve natural systems and resources to the Breatest possible extent.

(b) To this end, ERDA will incorporate into its planning and dectsionmaking processes, a careful consideration of the environmental consequences which may be caused by its proposed actions by:

(I) Evoluating both the long-range and short-range implications of such actyons to man, including his physical and social surrounding, and to nature:

(2) Exploring, developlng and aralyzing alternative actions that may avoid. minimize or compensate adverse impacts:

(3) Providing for disclosure of the potential environmental efrects of such proposed actions to agency and other decisionmakers, including Congress and the President, and to the public.

\$11.5 Applicability.

(a) This part applies to all ERDA organizations.

(b) This part covers ERDA administrative actions and legislative proposals. including those actions and proposals sponsored jointly with other agencies. In this latter connection. if an environmental impact assessment or statement is to be prepared, the agencies involved shall determine as early as posstble their respective responsibilities the preparation and processing of that document including designation of a single agency to assume leadership responsibilitles where appropriate. Where a lead agency prepares the document the other agencies involved are expected to provide assistance with 
respect to thetr areas of Jurisdiction and expertise. Fractors relevant in determinins an appropriate lead arency include time sequence in which the segencles become involved, the msrniltude of thelr respective involvement, and thels relative expertise with respect to the anticipated environmental effects of the proposed action. Whether an assessment or statement is prepared by a lead agency or is prepared jolntis by several asencies. the document should:

(1) Evaluate the environmental consequences of the full range of Federal actions Involved;

(2) Reflect the vews of all particlpatIng agencies;

(3) Be prepared before major or $15 r e-$ versible actions have been taken by any of the particlpating erencles.

(c) Thts part applies to proposed ac. tions which may have a slonticant environmental effect even though they arlse from projects or prosrams inltiated prlor to enactoment of NEPA.

(d) The following actions are not subject to the requlrements of this part:

(1) Administrative procurements (e.8. ceneral supplles):

(2) Contracts for personal services;

(3) Personnel actions:

(4) Legislative proposals originating In another agency;

(5) Legislative proposals not relating to or affecting matters within ERDA's primary a reas of responstbility:

(6) Legislative or administrative actlons in the nature of conceptual design. architectural and engineering studies, basic research, and other administrative matters or legislative proposals having no foreseeable impact on the quality of the human environment.

871.7 Definitione.

(a) An "action" as used in this Part is one which may afrect the quallty of the humen environment.

(1) An "admintstrative ection" is an ERDA action, other than a legtolative action (es desned hereln), which includes but is not necessarlly limited to:

(1) A new or continuine project or program. or expansion or reviston to a continuling program:

(A) Directly undertaken by ERDA:

(B) Supported in whole or in part through ERDA contracts, erants, loans. guarantees, subsidles, or other forms of inancial assistance:

(C) Involving an ERDA lease. permit. or license.

(ii) The establishment or modification by ERDA of rules, regulations, or policies.

(2) A "budgetary action" is a legislative action (as defined hereln), involving an ERDA request to Congress for authorization and appropriation of funds for a proposed construction line item, or other proposed major activity or program.

(3) A "legislative action" is a favorable report or recommendation on a proposal for legislation sponsored by ERDA. including a budgetary action as defined herein.

(b) An "environmental development plan" (EDP) is generally anticlpated to be the baslc ERDA management document tor planning, budseting, manasins, and revlewing the broad environ. mental implications of an ERDA enercy research, development and demonstration program.

(c) An "environmental impact asseasment" (EIA) is a written document which evaluates the enviranmental im. pacts of proposed ERRDA actions to as. sure that environmental values are considered at the earliest meaningful point in the decisionmaking process, and whlch provides the basls for a determination whether an environmental im. pact statement will be prepared.

(d) An "environmental impact statement" (EIS) is a written document propared at the earliest meaningful point in the dectstonmaking process which analyzes the environmental impacts ascoclated with a proposed IRRDA action and of reasonably avalleble alternative and refiects responstble publlc and covernmental vlews and concerns.

(1) A "draft environmental impact statement" (DEIB), 18 a prellminary statement which is clrculated for review and comment outside of ERDA as a vehicle for eliciting additional public and governmental participation in the ERDA environmental review process.

(2) A "Anal environmental impact statement" (FEIS) ts a revised DEIS which considers and evaluates (a) the substantive issues and comments raised and (b) new information developed during the public review period.

(e) A "negative deolaration" is a document prepared subsequent to a decision that an environmental impact statement will not be prepared for a proposed action where the action is one which: (1) Elas been identifed earller in an EDP or EIA as an action for which a statement would be prepared: (2) Is simillar to acHons for which ERDA has prepared a doniflcant number of itatements; (3) Eis previously been ansounced as being the subject of a statement; or (4) ERDA has determined not to prepare such a statement in response to a request from CEQ to prepare atatement. Thls document ohall set forth the dectsion and briefly state the reasons therefor.

(l) "Programs" are artregates of projects which share a common objectlve or purpose and are so Inter-related that planning or decisionmaking with respect to any one component would be likely to stgnificantly affect planning or decisionmaling with respect to any other component.

(g) "Projects" are individuallzed ERDA actions including, but not limited to. proposed construction of a facility which may, but need not, constitute a part of a larger program.

(h) "Responsible Assistant Administrator" is that Assistant Administrator who has been assigned overall responsibility for the conduct of a program, project, or other ERDA action which may be subiect to this Part.

(i) "Appropriate ERDA official" is the program division, fleld organization, or any other subunit head within ERDA who has been assigned direct respons!billty for the conduct of a program, proj- ect, or other ERDA action subject to hils Part.

(j) "Bummary sheet" is a brtef summary of the signiflcant aspects of an environmental impact statement which accompanies the EIS. It is prepared in accordence with Appendix. I of the CEQ Guldellnes (40 CFR 1500).

Subpart B-Environmental impact Assestments

711.23 Criteria for determining need for environmental impact assect. ments.

(a) An environmental impact assess. ment is ordinarily not required for acthons and alternatives with respect - to whlch an environmental impact assess. ment or statement has been formerly prepared by ERDA or another Federal urency and that in the opinion of the Avs still refects current evaluation of such impacts and 1ssues. In these instances, the relevant assessment or statement thould accompany the proposal for such action through the ERDA review and decislonmaking process to the same extent as an assessment or statement prepared under this Part.

(b) The appropriate ERDA offlials are responstble for the preparation of environmental impact assessments for all proposed administrative and legislative actions to which this Part is applicable and have not been previously identifled as requiring environmental impact statements.

(c) The Asststant Administrator for Environment and Safety (AES), in consultation with the Omce of the General Counsel (OGC), may request the responsible Assistant Administrator or appropriate ERDA offlctal to prepare an environmental impact assessment for any proposed ERDA metion under their respectlve Jurisdiction, which, in the opinion of the AES, may impact the quallty of the environment.

711.25 Content of environmental im. pact ausesuments.

(a) Invlronmental Impact sssessments (EIA) should be brief, factual documents that evaluate and analyze the environmental consequences of proposed ERDA actions in enough detall to es. sure that environmental values are considered as early as possible in the declslonmaking process and to provide the factual basis for a determination of the need for the preparation of an environmental impact statement. Assessments should be structured in a manner that is most useful for planning and decisionmaking. EIA's should ordinarily contaln the following Information:

(1) Description of the proposed action. The proposed action should be briefty described and known environmental issues should be identifed. Drawings, maps, and charts should be Included only if directly pertinent to the assessment.

(2) Description of the extsting environment. The existing environment affected by the proposed action should be described only in sumplent detall to permit a meaningful evaluation of the 
potential envtronmental consequences of the proposed sction.

(s) Potential enotronmental impacts. The potenttal impacts and ribs of the proposed action should be enewed, In aluding those adverze impacts which cannot be avotded should the proposal be implemented. The potentivl cumula the and. Jong-term environmental ef lects, Incluaing any bentactal efrects should also be evaluated. Any known issue identified in subparagraph (1) above. should be discussed. The risks and enect of signtacant credible acctdents should be evaluated For proposed construction projects, potential impacts in the following three areas hould be addressed:

(1) Construction. The probable environmental effects that may occur from site preparation, roads, excavation, util1tles, parking Jots, haullng, clean-up etc. should be assessed. Included should be the efrects of dust, earthmoring, silt, Water and notse. Secondary impacts such as increased labor force and efrect on community resources, ind new housIng and services, should be discussed Whenever appropriate.

(ii) Operation. The probable environmental impacts from the use of resources, such as materlals, supplles, fuel, personnel, and from plant amuents should be assessed.

(i11) Site restoration. The plans, 1 any, that may be required for site reotoration and the resulting impacts hould be brietly described.

(4) Coordination with Federal, state regional or local plans. The potential conflicts of the proposed action with Federal, state, regional or local plans and policies and how any conflicts will be mitigated or resolved should be described.

(5) Description of alternatives. The reasonably avallable alternatives to the proposed action should be brlefly described.

611.27 Submission of environmental impact assessments.

(8) Environmental impact assessments shall be submitted to the AES through the responstble Assistant Administrator along with a recommenda tion as to whether an environmentel impact statement should be prepared and the reasons therefor. If it is recommended that a statement should be prepared the transmittal shall include the information specifed in 1711.47 (b).

811.29 Review of environmental impact assessmento.

(a) The AIS, in consultation with OCC, shall revlew envtronmental impact assessments and accompanying recommendations in accordance with 711.41 to determine whether proposed actions require the preparation of an environmental impact statement.

(b) If the AES determines that a statement is required, he will so inform the responsible Assistant Administrator who shall cause the preparation of an environmental impact statement in ac. cordance with 711.47, and Subpart $D$ (c) A copg of all enviranmental mpact

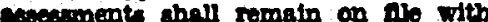
Ars tho shen plece coptes of melasedned documents in epproprtate BRas. public document room (a) for public inapection as toon as posstble. Onless or until superseded by an environmental impact statement, enviranmental impact arsessments hall accompany the proposed action through the agency deciclonmaking process.

\subsection{Negative declarations.}

(a) If it is determtned that e proposed action does not require the preparatton of an environmental impact statement and the proposed action meets the criteris of $/ 711.7(e)$, the ADS shall so in form the approprtate ERDA officlal and cause a negative declaration to be prepared which documents the reasons for that determmation. Negattve declarations shall be published in the Fedran RrGIstra. No action related to the subfect of the negative declaration shall be taken sooner than 15 days following pubUlcation in the FrozRAL REGISTKR.

(b) Itsts of negative declarations shall be provided to CEQ at least quarterly in accordance with $10 \mathrm{CFR} 1500.6(e)$.

Subpart C-Environmental Impact Statements

611.41 Crtheria for determining need for environmental impact statements.

(a) An environmental impact statement is ordinarily not requlred for actions with respect to which an environmental impact statement has been formerly prepared by ERDA or another Federal agency and that in the optnion of the AES stiul reflects a current evaluation of such impacts and the issues involved in ERDA's Implementation of the proposed action. In these instances, the relevant statement ahould accompany the proposal for such, action through the ERDA review and decisionmaking process to the same extent as a statement prepared under this Part.

(b) Environmental impact statement shall be prepared for those proposed actions identified tn current environments development plans as requiring ouch statements except as provided in 8711.3 and all other major FRDA actions having a potentially sisnificant effect on the quality of the human environment.

(c) In determining what is a "major ERDA action having a potentlally significant effect on the quality of the human environment", the following should be considered:

(1) The torm "major GRDA actions" implles a threshold of magnitude of ERDA involvement which must be me before a statement is required. The action must be one where there is sufficien ERDA control and responsibulity to inHuence the course of the action. In assessing the nature of the action, the role of ERDA funds, manpower, studies and discretionary decisions should be considered.

(2) The term "significantly affecting the quality of the human environment" implles a threshold of impacts which must be met before a statement is regutred In ussessing the etronincance of tho tmpect the following should be convidered:

(i) The overall cumulattve tmpact of tho proposed action and related Federal

(ii) The potential for desradation of the qualtty of the environment, curtall. ment of the range of beneflctal uses of the environment, and the furtherance of ghort-term to the disadvantage of longterm environmental goals:

(1ii) Erects on management, allocathon or consumption of important scarce or nonrenewable resources; and

(Iv) Whether expected environmenta impacts are ilkehy to be controverslal.

(3) Bignificant effects may Include secondary erfects such as socioeconomic impacts and actions which could have both beneficial and adverse efrects. Additional guidance is set forth in the CEO Guidelines, 10 CFR 1500.6 (a), (b) and (c).

8711.43 Scope of environmental impact otatements.

(a) Programmatic environmental impact statements. The scope of programmatle environmental impact statements should be determined on a case by case basts. The following is provided as general guidance only:

(1) Environmental impact statements covering a program as defined in 711.7 (f), generally shall assess all reasonably foreseeable envtronmental consequences generic to component subprograms, projects, and actions; and shall focus on the cumulative effects of such related activities. In general, an analysis of speciffe impacts and alternatives dependent upon design, slte, or other speciffic details of component projects or actions should be treated in environmental impact assessments or statements for specific projects or actions.

(2) Environmental Impact statements covering technology research, development, demonstration, or commercializatjon programs generally shall discuss the anticipated impacts of commercial deployment of such technology, includ. ing discussion of any major uncertalnthes with respect to the environmental effects of such deployment.

(b) Project environmental impact statements. Environmental impact statements covering projects ordinarly hould focus on the localized environ mental impacts of a speclfic proposed action, such as the construction and operation of a proposed factlity at a specinc site.

(c) Site environmental impact statements. Fnvironmental impact statements covering a site under ERDA jurisdiction generally should assess collectively the environmental consequences of a num ber of continuing and/or proposed individual actions such as the operation of factlities at the given site. They should also discuss the interrelationship of the cumulative environmental effects from past activities at the site with those expected trom continulng and/or proposed activities at the site. 
1711.45 Timing of envirosmeatil tor. pact ctatements.

(a) Prostammatic environmental Im. pact statements. The planned timing for preparation of a prostammatlc environ. mental impact statemeat shall bo deter. mined on a case by case basls and Identifed as appropriate in the environmental development plan for the specinc program.

(1) For research, development and demonstration programs, a programmatic environmental impact statement should be written late enough in the developmeris process to contain meaningful Information on the effects of application of the technology. However, It should be written early enough so that the environmental Information contained can be factored into the declstonmaking process before the development process has reached stage of investment or commitment to implementation likely to determine subsequent development or to foreclose or restrict later alternatives. Therefore, the following eactors, among others, should be evaluated and periodically reevaluated iparticularly when new information becomes avaliable concerning the potential environmental impacts of the program) to determine the appropriate polnt for preparation of a program statement:

(1) The magnitude of Federal investment in the prosram

(if) The likelihood and proximity of widespread application of the technology.

(iii) The degree and controverslal nature of the environmental effects of the program. Indlvidually and cumulatively which are likely to occur in the event the technology were widely applied.

(ty) The pace at which the program is moving from basic research toward demonstration of a viable technology.

$v$ The extent to which continued in vestment in the new technology is likely to foreclose or restrict future alternatives.

2. For commercialization or other programs not identifled in paragraph (a) (1) of this section. a programmatic en vironmental impact statement should be written late enough in the formulation of the proposed program to contain meaningful information on the likely environmental impacts of implementation but early enough so that the environmental information contalned therein can be factored into the decisionmaking process prior to the foreclosure or re striction of reasonable altermatives.

(b) Project environmental impact statements. The environmental impact statement shall be prepared late enough in the development of the proposal to contain meanlugful information on the potential localized environmental im pacts at the site of the construction and operation of a proposed specific research. development, demonstration, or commer cial facility but early enough to provide meaningful environmental input into the decisionmaking process. In all cases the statement should be prepared befor major resources are irrevocably or irre- varibly committed and prior to taking an action with respect to the proposed project that has a potential for strin. cant environmental tmoset.

(c) Lerislative actions involving environmental impact statements. To the maximum extent practicable anal environmental impact statements hould be prepared in time for consideration by the Adminlstrator before submisston to the Congress of IRDA Ieglslative sctions. In cases where that is not practical and where the scheduling of Congresstons? hearings on wach actions do not allow adequate time for the completion of inal environmental impact statement, draft environmental impact statement may be furnished to the Conzress with transmittal of comments as recefved. In any event, the text of the inal environmental impact statement should be made avallable (1) when completed and (2) prior to administrative implementation. 8711.47 Reaponsibilities for prepara tion of environmental impact statements.

(a) Appropriate ERDA onctals shall undertake the preparation of environmental impact statements in accordance with 711.43 and Subpart $D$ for proposed actions identified as requiring the preparation of an EIS (1) in an appropriate environmental development plan. (2) in accordance with 111.29 , or (3) by the AES, after consultation with OGC and the responsible Assistant Admints trator.

(b) Before preparation of an environmental impact statement is inittated, the approprlate ERDA officlal shall subm! through the responslble Asslstant Ad ministrator the following information to the AES for concurrence:

(1) A description of the proposed action and scope of the document.

(2) An outline of what is intended to be discussed in the statement, Including identification of known environmental Issues.

(3) The alternatives which will be analyzed.

(4) The anticipated dates of issuance for both draft and final statements.

(5) A description of actlyitles, if any which will continue, commence or occur with respect to the subject of the document prior to 30 days after issuance of the final environmental impact statement.

(6) Recommendations as to the need for, and composition of, intra-agency or inter-agency task forces to prepare or assist in the preparation of the environ mental impact statement and the sug gested composition.

(7) A recommendation regarding the desirabllity of a folnt statement with the participation of other agencies in light of $\$ 711.5(\mathrm{~b})$, and, if so, the con ditions under which such participation should proceed.

(c) If after consultation with OGC the AES concurs in the approach de scribed pursuant to paragraph (b) of this section. he shall advise the appropriate ERDA official to commenee preparation of the environmental impact statement and shall publish a notice of intent pur- mant to 711.49. If efter consultation with OCC, the Ars does not concur he chall edvise the approprlate IRDA of flcial of the modifcettons whlch will be required to obtain AES concurrence.

\subsection{Notice of intent.}

(a) After determination has been made to prepare an EIS, the responstble Assistant Adoninistrator, at the direction of the AES, shall cause to be submitted to the ADS:

(1) A Notice of Intent to prepare an environmental impact statement which:

(1) Describes the proposed action and proposed scope of the document in suriclent detall to promote responsive comment.

(11) Lists the alternatives to be analyzed.

(iii) Indicates the location(s) of known documentation to be utilized in the preparation of the statement.

(iv) Invites comments and suggestions for consideration in the preparation of the environmental impact statement.

(2) A list of -individuals or organizations whom the appropriate ERDA off clal has identified as having interest in the environmental Implications of the subject action.

(b) Whenever practicable, the AES shall cause to be published in the Fro. erar Register the Notice of Intent to prepare the environmental impact state ment and shall transmit a copy of tha Notice of Intent to appropriate Federal. state, and local agencies and to persons or groups known to be interested in the environmental implications of the proposed action.

8 711.51 Required lists.

(a) The $A \mathrm{ES}$ shall be responsible for the preparation and maintenance of:

(1) Lists of actions for which environmental impact statements are being prepared

(2) Lists of actions for which negative declarations have been prepared.

13) Lists of persons or groups known to be interested in the environmental implications of specific ERDA actions (interest lists)

(b) The AES shall revise lists ( 1$)$ and (2) in paragraph (a) of this section at least quarterly and shall transmit a copy of those unclassifled lists and subsequent revisions to CEQ

(c) The AES shall complle list (3) in paragraph (a) of this section from those individuals or groups who have either

(1) Requested that copies. or notification of avallability, of draft environmental impact statements be sent to them.

(2) Commented on a previous draft environmental impact statement.

(3) Participated in a public hearing held on an entrouniental Impact statement.

(4) Been identifled by the appropriate ERDA official as having an interest in the environmental implications of a proposed ERDA action

(d) List : 3 , in paragraph (a) of this section shall be maintained in accordance with the provisions of the Privacy 
Act of 1974 (Pub. I. 93-679, 6.8.C. (52a)

(e) Individuals or organtrations dosiring to be plisced on specticl interest Lists or to requeat coples of environtlons of Intent to prepare wich statetlons of Intent to prepare wich statements should address their requests to: erey Research und Development Admintstration, Washington, D.C. 20545.

6711.53 Submiseion and review of draft environmental impact statements.

(a) Internal revlew and approval of draft environmental impact statements.

(1) The appropriate $\mathrm{ERDA}$ oficial chall submit the draft envionmental impact statement (DEIS) through the responslble Assistant Administrato

(2) the AOB shall be asststed in hls revtew by OCC and an Interdisciplinary Revtew Committee (IRC), chaired by the Director of the Ofice of NEPA $\mathrm{Co}$ ordination, or his representative, and compased of such representatives of LRDA Headquarters and Ald organizations as the A Aps deems appropriate.

(b) External review of draft environmental impact statement Upon the com pletion of ERDA's revfew, the AES shal make the draft environmental Impact statement and Summary Bheet avallable to the CEQ, and soliclt comments from approprlate Federal, state and local agencies and organizations and individuals. He shall publish a Frorrat RrGustrR notice of the public arallabllit and the comment period for the drat environmental Impact statement, and make coples available for comment upon request. Coples of the Fedran Recrstr: notice will be made avallable to those on the appropriate Interest Iist. Coples of the DEIS will be placed in appropriate places for public inspection.

(c) Commenting entities should endeavor to furnish comments on draft environmental statements which follow the format of the statement wherever practical and should be as spectic, substantive and factual as posstble withou undue attention to matters of form in the statement. They should place emphasis on the environmental impacts of the proposed action and the acceptability of those Impacts on the quality of the environment particularly as comthe environment particularly as comreasonably avaliable alternatives. Com menting entities may recommend modifcattons to the proposed actJon and/or new alternatfres that they belleve wil enhance environmental quality and avold or minimize adverse environmental impacts.

(d) Comments on the draft environmental impact statement shall be considered in the flnal environmental Impact statement if recelved by the Direcpact statement if received by the Director, Oflice of NEPA Coordination withtn CEQ and ERDA Notices of Avallablity of environmental statements in the FrDcral Register. A 45 calendar day comment pertod will be used unless a different perlod is specified in the ERDA's no-
Hce of erantebltity of the draft statenent covering the proposed sction.

(e) The Airs, upon request, mar mant extensions of the for recelpt of com. ments for wch pertods as he deems appropriate. In determining the approprtato perlod for comment or in -ectins. upon an extenston request, considers. upon an extenston request, considerscomplexdty of the statement, and the extent of public Interest in the proposed action. Where no time extension has been requested and rranted and comments are not recelved wthin the desIgnated comment perlod, it ahall be conclusipely presumed that no comment is to be made.

8711.55 Public hearints.

(a) The Ars determines, in consultation with the responsdble Assistant Administrator and OCC, whether a public heartng would be approprlate and in the publlc interest considering among other things:

(1) The magnltude of the proposed action in terms of economic costs, the ceographtc urea involved, and the uniqueness or slze of the commitment of the resounces involved;

(2) The degree of interest in the proposed action, as evidenced by requests from the public and from Federal, state. and local authorities that a hearting be held

(3) The complexity of the Issues and the likelthood that additional Information will be of assistance to the agency in fulfiling its responsiblitiles under NEPA; and

(4) The extent to which public In volvement already has been achleved through other means, such as earller puble hearings meetings with citizen representatives and/cr written comment or suggestions on the proposed action.

(b) If it is determined as set forth in the above paragraph that a publlc hearing is to be held, the Ams will issue a

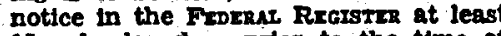
15 calendar days prior to the time of such heartng which will:

(1) Identify the subject matter of the hearing;

(2) Announce the date, time and place of such hear:

(3) Indicate the avallabillty of the draft environmental impact statement. the comments, if any, recelved to date. and other data, as determined appropriate, for public inspection. The hearin will also be announced through loca news medis when practicable.

(c) Written notification of the scheduling of a public hearing, providing the information referred to in paragraph (b) of this section, shall be sent to all percons and organdzations known to be in terested in the action, including those who have commented on the draft environmental impact statement, and those who have requested coples of such statement.

(d) Public hearings will be legislative rather than adjudicatory in nature with no Hight to formal discovery, subpoen of witnesses, cross-examination of par- thotpants, testhimony under ath, and other imiliar lormalittes more approprlto to an adjudicatory procedure. OCC thall prescribe the detalled procedures to be followed for ipecific hearings.

(c) Public hearings will be conducted by

(1) After the close of the hearing, a hearing record will be prepared which consists of the transcript of the heartns and ill documents, exhtbits and other papers received into the record by the Preslding Board. The Prestding Board shall render a report based upon its reWew of the draft environmental impact statement, the comments recelved thereon, and the hearing record and shall forward its report, together with the record. to the APS. The report shall (1) Identify unresolved issues raised at the hearing which the Prestding Foard deems to be matertal to future decistons concerning the subject matter of the environmental impact atatement, and (2) include recommendations concerning the treatment of these Issues in the nnal environmental impact statement in a manner to promote informed dectslonmaking. In discharging its functions, however, the Presiding Board shall not undertake to resolve issues or. render judgment concernIng the proposed action.

(g) The hearing record and the Board report shall be placed in appropriate places for public inspection and consid lace in the preparation of the final environmental impact statement. The text of the Board report shall be appended to the final statement.

711.57 Preparation, review and dis tribution of final environmental impact statements.

(a) Preparation of final environmental Impact statements. As soon as practicable after the expiration of the written comment perlod and the closing of the public hearting record, if any, the approprtate HRDA oficial shall initlate the preparation of the final environmental impact statement end summary sheet. taking into account all substantive writ ten comments recetved, the hearing record, the Board report and new information developed during the review period The fnal environmental Impact statement shall include a meaningful, obJective and informative treatment of all ubstantlve issues rafsed, Including description of known responsible vlews on such issues. The text of all comments recelved, and the Board report, or sum marles thereof, shall be appended to the statement.

(b) Internal review of final environmental impact statements

(1) The appropriate BRDA onclel shall submit final environmental impact statements (FEIS) through the responsible Assistant Administrator to the ARS lor review.

(2) The AES shall be assisted in his review by OCC and an Interdisciplinary Review Committee (IRC), chalred by the Director of the Office of NEPA Coordination or his designee.

(3) Upon completion of Ams review and approval of the F'cIs, the responsi- 


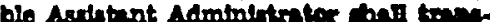
mitt the Fis through the AD to es

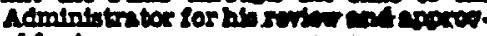
al 20 invance.

(c) Dinterbutton of Anal cavironinonter impect itatements.

(1) Upon recolpt of Adminiatrator epproval, the ATH shall:

(1) Blen the FELIS and distributo tho statoment and Bummary Bheot to Cro EPA, and Foderal, 8tato and local agencles, and others who submittod timols commenta, particlpeted in the publlo hearing on the draft environmental im. pact statement, or requested o cops of the FIHIS prtor to It tsourance. In the case of Fitss on leglslative sctions approved by the Administretor, the AMS chall aubmit the statement to the Conress and the Oxas

(ii) Publish 72-6. Notice of A raflebnity of (ii) Publlsh a Notice of Araflability of notice hall include the location(s) at which the statement is arailablo for pubItc tnspection and where coples and bo obtalned.

(111) Transmit coples of the Finis to appropriate IRRDA public document room (t).

8711.65 Timing for propocod ERDA actlons.

(a) Irrcept in spoctal cases when approval is efven after consultation with CIR no proposed IRDA cotton far whlch in environmental impect itatoment is prepured shan bo taken

(1) Sooner than 90 calendar days after a draft environmental tmpact itatement has been lssued; or

(2) Eooner than 30 calendar dase after the Anal environmental tmpact statement has been lssued. (Thils period may run concurrentis with that in paragraph (a) (1) of this document).

8711.67 Amendments or supplements to final environmental impact statoments.

(a) Blace the ERDA environmental review process is designed to rubject ERDA actions to formal review at the earliest stages in their development. It is recognized that sdditionsl reviews may be necessary or destrable is the action evolves and matures. Accordingly, whenever substantial new information pert1nent to en extuting flnal environmental tmpact etstement becomes araflable, or Thenever substantial modinceations of an wction covered by mab anal statement occurs, the approprtate ERDA onctal shall consult with AES and OCC to dotermine whether to amend or supple. ment the exdsting anal environmentel impact atatement.

(b) When a determination is made to prepare ouch a rupplement or amendment, the resulting document shall be subject to the procedures coverning draft environmental impact statements under this Part uniess, after consultation with $O C C$ and CEQ it is determined by the Ars that circulation for comment is unnecessary. In that erent, the document shall be subject to the procedures boverning nnal environmental impact statements under this part.
11269 Dorkar of ether agoncies" en-

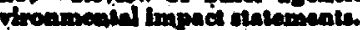

c) Itr Onos of WMPA Coordinatton thir mintitis a lint of environmenta tropot statement recolved from other eronoter for comment and ahanl Identity show environmental tmpact tatement wheh inrolive mutters of interest to Frad div to furtadietion by law, Ipecial Tortise or other dise.

(b) Environmental impact statement co sdentiled shan bo transmitted to the appropriate EMRA orrantzational unit. Lar review and comment. Review and commient shall be conducted according to the instructions of $10 \mathrm{CFR} 1500.9(e)$. ERDA reviews should Identify possible conflicts with known current or future procrams, Indicate areas of research which ero underway or planned by IGRDA which min currest new elternatives, Wass to mitteats efrects, or gaps in the tato of relerant boowledge and offer comments in WRDA areas of Jurlsdiction b5 hit and apecial expertise.

(c) Euch comments aball be trans. mitted to the Omoe of NEPA Coordine. too who shall coordinate the comments and forward them to the inftlating arenoy and the CEQ

subigart D - Coneral Quldance for Content of Envronmental impact statements

711.81 Cover.

The cover thall indicate the tspe of thatement (draft or Anal), the ofleth profect tttio and location, the month that the statement is lesued, the asencs and for fnsi tatements, the atronsture of the iseruting ofinctal on the title page.

\subsection{Body of atatement.}

(a) Eech environmental impact statement should be prepared in accordance with the precopt to rection 102 (2) (C) of the National Environmental Pollcy Act of 1960, that all arenctes of the Federal goverament "utillze a cystematic, Interdrotolinar approach which ofli tinsure the interrated use of the natural and coctal sciences and the environmenta deden arts in planning and doclsionmakIng which mas have an impact on man's environmont." The statement ahould be ractual and objective eveluation of actions and their reasonable alternatives in Lirht of enviranmental considerations The presentation should be (1) conctse. mahuding or referencing relevant dats. information, and analyses nocessary to permit independent evaluation and appraisal of the envitronmental effects of the proposed mad action and its resconable alternatives, and (2) strictured in a manner that is most useful for planning and decislonmaktng. Btatements hould not be drafted in a ttyle which reoutres extensive sctentitec or technlcal xportise to comprebend and should focus on environmental iscues relevant to tho proposed action. Underistins studies reports and other Information obtalned and considered in preparing the state mont should be identifed at approprtate polnts in the text. Flohly technlcal and pectalized unalyses and dats should bo avolded in the text but should be attached as appendices or referenced with footnotes. Where there are references to documents not likely to bo eanils scoesdible, wuch as internal atudilos or reports the ctatement thould rummariso whorover practloablo and indlonto how wach information mis be chtaliod Man ereluations of environmental trapect $x^{0}$ trvolve mecurrements enabses, calcrslatione, and decton druirings much too voluminous to be included to en environmentel tmpact itatement of workeble length. In thase cares, it will not be pos tblo for the reader to make a completely independent erpaluntion of environments impact from the thetement itself. How cror. It thould be posuble for the reader to understand from the toxt combtned with the appendices and references, the topes of tmpact which have been conIdered. the reneral methods of evaluatron used and the types of dats behlnd them, and the factual conclusions reached.

(b) Each statement shall disclose and craluate the environmental trade-orf of proposed sctions and of ressomsbly arallablo alternatives in mumctent detait to permit in independent appralsal of the environmental aspects of the proposed action in relationshto to alteros-

(c) Erach statoment thall discuse or refor to responnible vews rerarding the eaviranmental impacts of the proposed cotion. Bubetantive currestions and com monts mado by other Fodern, state, and local agencios and b5 privato orranizations and Individuale prior to proparation of the environmental impect statement (draft or and) shall be ldontined and analyzed in the appropriate sections of the araft itatement. Blmilarly, substantwe comments recelved as a result of revien of the draft statement shall be considered in the preparation of the ins tatement.

(d) Environmental Impact statements ordinarily should contatn the following iformation:

(1) Summary. The saltent information and factual conclustons of the enTronmental statement should be conctsely rummartzed at the bestnnting of the document. Emphasis should be on any unresolved environmental issues and on factural conclustons concerning the Atraticance of the impacts associated Fith the proposed action and the relstive mertits af alternatives.

(2) Description of groposed action. The proposed action, its purpose and the polley objectives and tanifible benest both short- and lons-term, wourht to be realised by implementation of the proposed action thousld be brienty described Amonr factors to be described are the location and duration of the proposed action; histortcal information necessary to place the proposed action in proper perspective; its relationshts to other projects or prorranas of the Foderal Corcrnment; and an overall phosical do corfption if epproprtate, emphestain Seatures with envtronmental edentincance The enpironmental controls and other mittigating measures, thcluding plans for dite restoration. that are destrined into the proposed setton should also be described.

PEDERAL REGISTER, YOL 42, NO. 17-WEDNESDAY, JANUARY 26, 1977 
(8) A characterization of the extinting crivironment ikcely to be affected by the groposed action. A brtes overvien of the eroposed action. A bres of the areas ifiteenvironmental features of the areas intoIy to be affected by the proposed notion hould be described in arder 10 provide baseline for analysis of exviranmental impacts. Wherever approprtste, en Ident.fication thould be made of population areas and of the current uses of ruch areas. Detalled descrtotions of the edsting environment thould be dither in cluded in an appendts to the statemen or referenced in the tort, when necessar for a thorough understanding of the environmental impllations of a proposed action. The amount of detall provided should be commensurate with the exten of the expected impact of the action, and the amount of miormation required the partic

(4) Potential environmental impacts of the proposed action. The probable environmental impacts of the moposed action (assuming implementation of proposed mitigating measures) should be analyzed in order to cletermine what, $t$ any, environmental lssues may be involved in the proposed action. In 80 doing, the analysts should describe those effects on the environment, benefictal a well as adverse, which could be caused by the proposed action, evaluate the mag nitude and importance of each such elfect, and identify the time frames in which these effects are antictpated. An unknowns as to the probable environmental impacts should be clearly identtned. The probable primary (direct) as Tell as secondary (indirect) environmental consequences should be ussessed. In this context, "secondary" consequence refer to associated investments and changed patterns of social and econamle activities likely to be induced by the proposed action. Such secondary efrects, through thetr impacts on existing community faclitiles and activities and through changes in natural conditions, may be more substantial than the primary effects of the proposed ection. The extent to whtch the proposal will conform or conflet with any appllcable Federal, State, or local statutes, regulations, standards limitations, and pollcles respecting environmental quality (alr and water quality, wastes, pestlcides, etc.) should be discussed. The risks attributable to acctdental or Intentional environmental destruction as well as to normal operations should ilso be assessed. Risks should be expressed in terms of probablity of occurrence and magnitude of consequences to the extent practicable.

(5) Unavoidable adverse environmental effects. Adverse environmental eflects that cannot be avoided should the proposed action, with its environmental protection strategy, be implemented, and the magnitude and importance of each such effect, should be briefly summartzed.

(6) Irreversible and irretrievable comintitment of resources. The extent to which the proposed action would consume, destroy, or transform scarce or nonrenewable resources, thus curtalling the diversity and range of potential uses of the environment should be cummsised. In this contert, "resources" means rabor and materinls devoted to the proposed sction is vell es natural and ouluril resources.

(7) Relationship of land use plarw. pollctes, and contrals. For profect or stre statements, there should be in eraluaton of how the proposed ection may conform or confict with the objectlves and pectic terms of approved or proposed Federal, Btate, and local land use plans, policies and

(8) The relationshtp between shortterm uses of the envtronment and the maintenance and enhancement of lonoterm productiolty. The extent to whtah the proposed sotion rould constratn the diversity and rance of potential uses of the environment, including nonutllitarcussed. The cumulative and lons-term environmental effects of the proposed ection should be assessed from the perspective that each seneration is trustee of the enviranment for succeeding generations. Thts involves consideration of the present conditton and ise of the site of the proposed action, its use if the proposed action is implemented, and the long-term prospects for other uses. A brlef assessment should be made of the extent to which the proposed action in. volves trade-ors between short-term gains at the expense of long-term losses, or vice versa, and a discussion of the extent to which the proposed wotion and its alternatives foreclosed future options. In this context, short-term and long-term do not refer to any nxed perlods but should be viewed in terms of the environmentally stgnificant consequences of the proposed action.

(8) Alternatives. A rigorous exploration and factual evaluation of the envi. ronmental impacts of the full range of reasonable avallable alternatives to the proposed action should be presented. In particular, reasonable alternatives to the proposed action that misht be spectf cally formulated to enhance environmental quallty or to aroid, mitigate, or compensate for some of the adverse en. vironmental effects should be discussed, e.F. environmental protection strategles beyond those destgned in the proposal. The specific alternative of taking no ac. tion hould always be evaluated. Examples of other alternatives include: the altermatlve of postpontng action pending further study; alternatives requiring actions of a signifleantly different nature whtch would provide stmilar benefits with different environmental impacts; altermatives related to different designs or detalls of the proposed action which would have different environmental impacts, and alternatives to provide for compensation of .nsh and wildife loss, Including the acquisition of land, waters, and interests therein. In each case, the analysis of alternatives should be suticiently detalled to permit comparative evaluation of the environmental tradeoffs of the proposed action and each reasonable alternative. Where an existing impact statement already contains an analysts of an alternative $(8)$, its treat- ment of the alternative (s) may be summartsed and incorporated by reference prorided that mah treatment is current and relevant to the prectse objective of the proposed sction. The range of alternatives chould not be limited to measures which the agency has authority to adopt but thould include a meaningful discusston of all reasonable alternatives to the proposed action. 1 more detalled analysis hould be made of the environmental impact of alternatlves that can be implemented within the same time irame as the proposed action than for those alternatives within different time frames.

(10) Environmental trade-of analysis. At the conclusion of the statement there should be $\mathrm{e}$ synthesis of the information contained in the body of the statement and analysis of the environmental tradeoffs assoctated with the proposed action and reasonably avallable alternatives. This enaigsis should be sufficlently detalled to permit an independent evaluation of the effects assoclated with the proposed action and each reasonably arallable alternative so that an informed of undertaking the proposed action rather than one of the alternatives (including the alternative of no action).

[7R Doc.77-2542 Flled 1-26-77;8:45 am] 
APPENDIX 2.

FEDERAL REGULATIONS APPLICABLE TO

GEOTHERMAL RESOURCE DEVELOPMENT PROJECTS 
APPENDIX 2. FEDERAL REGULATIONS APPLICABLE TO GEOTHERMAL RESOURCE DEVELOPMENT PROJECTS

\section{Geothermal Steam Act of 1970 (Public Law 91-581, 84 Stat. 1566)}

The Geothermal Steam Act authorizes the Secretary of the Interior to make disposition of geothermal steam and associated geothermal resources: (1) in lands administered by the Secretary, including public, withdrawn, and acquired lands, (2) in any national forest or other lands administered by the Department of Agriculture through the Forest Service, including public, withdrawn, and acquired lands, and (3) in lands which have been conveyed by the United States subject to a reservation to the United States of the geothermal steam and associated geothermal resources therein.

The rules and regulations implementing the Geothermal Steam Act have been specified (Vo1. 38, No. 245, Federal Register). These regulations provide a framework for leasing, exploration, development, and utilization of geothermal resources on public lands, consistent with multiuse management objectives. Geothermal Resource Operational Orders (GROs) issued by the Department of Interior under the authority of the Act include the following:

GRO Order 1. Exploratory

GRO Order 2. Drilling, Completion and Spacing of Geothermal Wells

GRO Order 3. P1ugging and Abandonment of Wells

GRO Order 4. General Environmental Protection Requirements

\section{Clean Air Act of 1970 (Public Law 91-604, 42 USC 1857 et seq.)}

Under the Clean Air Amendments of 1970, the Environmental Protection Agency (EPA) is required to establish national air quality standards as well as national standards for significant new pollution sources and for all facilities emitting hazardous substances. A hazardous substance is defined by the Act as one for which "no ambient air quality standard is applicable and which in the judgment of the EPA Administrator may cause, or contribute to, an increase in mortality or an increase in serious irreversible, or incapacitating reversible illness."

Ambient air quality standards have been established for the following six pollutants: : carbon monoxide, particulates, sulfur oxides, hydrocarbons, photochemical oxidants, and nitrogen dioxide. Of the six, the one of major concern to geothermal development is the standard for particulates. Emissions are not permitted to exceed 260 micrograms of particulates per cubic meter of air over 24 hours. For other air pollutants associated with geothermal development (e.g., $\mathrm{H}_{2} \mathrm{~S}, \mathrm{CO}_{2}$, radon) no national standards have been set. 
The Act allows the states to assume responsibility for establishing emission standards for existing sources, but their implementation plans are subject to EPA approval. This ensures that as a minimum, federal standards will be achieved at even the local levels. State and federal requirements are enforced by EPA either by order or civil suit, including injunctive relief. A private citizen may also bring suit to enforce the provisions of the Act. Prior federal or state authorization is required for the construction of certain facilities which constitute new sources of air pollution.

3. Federal Water Pollution Control Act Amendments of 1972 (Public Law 92-500, 86 Stat. 816 )

The responsibilities of the ERDA under NEPA are affected by the Federal Water Pollution Control Act (FWPCA). The FWPCA gives the U. S. Environmental Protection Agency. (EPA) regulatory authority over the discharge of pollutants to waters in the United States. Section 511 of the FWPCA provides that nothing under NEPA shall be deemed to authorize any federal agency to review any effluent limitation or other requirements established pursuant to the FWPCA, or to impose, as a condition of any license or permit, any effluent limitation other than any such limitation established pursuant to the FWPCA.

Pursuant to the authority of the FWPCA, EPA requires applicants for discharge permits to submit information required by EPA in order to establish effluent limitations permits. Pursuant to the authority of NEPA, the ERDA may require applicants/contractors for geothermal resource development projects to submit information required by ERDA in order to evaluate and consider the environmental impacts of any actions it may take. Consequently, the informational needs imposed by the two agencies may be similar in the area of impacts on water quality and biota. In addition, the FWPCA requires that EPA comply with NEPA regarding the issuance of discharge permits for new sources, as defined in the FWPCA, but not for other point sources.

In cases where the cooling system proposed in an application does not comply with the thermal effluent limitations under Sections 301 and 306 of Public Law 92-500 (FWPCA), a request for alternative thermal effluent limitations under Section 316 (a) may be initiated according to the provisions of 40 CFR Part 122.

4. Noise Control Act of 1972 (Public Law 92-574, 86 Stat. 1234)

The Act delegates the Environmental Protection Agency (EPA) with the responsibility to undertake a complete investigation of noise and its effects on the public's health and welfare. State and local governments have primary responsibility for the control of noise.

Although geothermal activities are not considered by the Act to be a major source of noise, EPA may be requested to assist a concerned community in determining appropriate noise levels and regulatory activities for a proposed geothermal project. 
5. Coastal Zone Management Act of 1972 (Public Law 92-583)

The Department of Commerce (National Oceanic and Atmospheric Administration) is authorized to make grants to the coastal states to assist in the development and administration of coastal zone management programs. The state program must define the controlled coastal zone (including adjacent shorelines the use of which could have a significant impact on coastal waters), define permissible uses and use priorities, and establish a system of legal controls for enforcement. The state program must be approved by the Department of Commerce with the concurrence of the Department of the Interfor. Once an approved state program is in effect, every applicant for a federal license or permit for an activity in the coastal zone must furnish a certification from the state that the proposed activity complies with the state's approved coastal zone management program and will be conducted in a manner consistent with the program.

\section{The Endangered Species Act of 1973 (Public Law 93-205, 87 Stat. 884)}

The purposes of this Act are to "provide a means whereby the ecosystems upon which endangered species and threatened species depend may be conserved, and to provide a program for the conservation of such endangered species."

The Act directs the Secretary of the Interior and the Secretary of Commerce to determine those species which are endangered or threatened. The Secretary of the Interior is then required to publish in the Federal Register a list (which from time to time he may revise or make additions to) of those species determined by him or the secretary of Commerce to be threatened or endangered.

The Secretary of the Interior is directed to enter into a cooperative agreement with any state which establishes and maintains an adequate and active program for the conservation of endangered and threatened species. To help implement a state's program, the Secretary of the Interior is authorized to provide financial assistance to the state.

7. Geothermal Energy Research, Development, and Demonstration Act of 1974 (Pub1ic Law 93-410, 88 Stat. 1079)

The purpose of this Act is to further the conduct of research, development, and demonstrations in geothermal energy technologies, to establish a federal Geothermal Energy Coordination and Management Project, to provide for the carrying out of research and development in geothermal energy technology, to carry out a program of demonstrations in technologies for the utilization of geothermal resources, to establish a loan guaranty program for the financing of geothermal energy development, and for other purposes.

The Act establishes the Geothermal Energy Coordination and Management Project comprised of six members, one being appointed by the President, who also designates a member of the Project to serve as Chairman of the Project. It makes the Project responsible for the management and coordination of the geothermal energy research, development, and demonstration program provided for in the Act. 
The Project's responsibilities under this Act are required to be carried out through specified federal agencies.

The Act also establishes the Loan Guarantee Program to encourage the commercial production of energy from geothermal resources.

For the protection of the environment, the Act requires that in the conduct of its activities, the Project and any participating public or private persons or agencies shall place particular emphasis upon the objective of assuring that the environment and the safety of persons or property are effectively protected. Under Title I the Project shall include such special research and development as may be necessary for the achievement of this objective.

8. Federal Nonnuclear Energy Research and Development Act of 1974 (Pub1ic Law 93-557, 88 Stat. 1878)

ERDA's responsibilities for the development of geothermal resources are affected by the Federa1 Nonnuclear Energy Research and Development Act of 1974. The Act authorizes ERDA to establish and conduct a comprehensive national program for the research, development, and utilization of all nonnuclear energy sources. Section 3 of the Act directs ERDA to incorporate the Geothermal Energy Research, Development, and Demonstration Act of 1974 into the national nonnuclear energy resources program.

A geothermal activity requiring significant quantities of water must be responsive to Section 5 of the Act, which states: "Any program for the development of a technology which may require significant consumptive use of water after the technology has reached the stage of commercial application shall include thorough consideration of the impacts of such technology and use on. water resources pursuant to the provisions of Section 13." Section 13 delegates the Water Resources Council with the responsibility to "undertake assessments of water resource requirements and water supply availability for any nonnuclear energy technology and any probable combinations of technologies which are the subject of federal research and development efforts authorized by this Act, and the commercial development of which would have significant impacts on water resources." 
APPENDIX 3.

STATE REGULATIONS APPLICABLE TO

GEOTHERMAL RESOURCE DEVELOPMENT PROJECTS 
APPENDIX 3. STATE REGULATIONS APPLICABLE TO GEOTHERMAL RESOURCE DEVELOPMENT PROJECTS

Information in this appendix has been obtained by reference to copies of applicable statutes and regulations of each state, as well as to a number of related publications, such as:

"State Policies for Geothermal

Development," Douglas M. Sacarto,

National Conference of State Legislatures,

1405 Curtis St. 23rd F1., Denver,

Colorado 80202, November 1976

"Geothermal Regulations," Special

Short Course No. 2, 23-24 May 1974,

South San Francisco, California,

Geothermal Resources Council,

P. 0. Box 1033, Davis, California 95616

Since statutes and regulations may be expected to be revised with time, the user of this guide should regard the information as typical and refer to the responsible state office or agency for current regulations. For this purpose, the responsible organization for each state is listed below:

\section{ALASKA}

Department of Natural Resources, Division of 0il and Gas 3001 Porcupine Drive

Anchorage, Alaska 99504

ARIZONA

Oil \& Gas Conservation Commission

4515 North Seventh Avenue

Phoenix, Arizona 85013

\section{CALIFORNIA}

Division of 0il \& Gas

1416 Ninth Street

Sacramento, California 95814

COLORADO

0il \& Gas Conservation Commission

Room 237 Columbine Building

1845 Sherman Street

Denver, Colorado 80203 
HAWAII

State Department of Land and Natural Resources Box 621

Honolulu, Hawaii 96809

IDAHO

Department of Water Resources

Statehouse, Annex 2

Boise, Idaho 83720

LOUISIANA

State Department of Conservation

P. 0. Box 44275

Capito1 Station

Baton Rouge, Louisiana 70804

MONTANA

Department of Natural Resources and Conservation

32 South Ewing

Natura1 Resources Building

Helena, Montana 59601

NEVADA

Division of Water Resources

201 South Fall Street

Carson City, Nevada 89701

NEW MEXICO

Oil Conservation Commission

P. 0. Box 2088

Santa Fe, New Mexico 87501

OREGON

Department of Geology and Mineral Industries

1069 State Office Building

Portland, Oregon 97201

TEXAS

Railroad Commission of Texas

$0 i 1$ and Gas Division

Austin, Texas 78700

UTAH

Division of Water Rights

Room 442 State Capitol

Salt Lake City, Utah 84114 


\section{WASHINGTON}

Department of Natural Resources

Division of Geology \& Earth Resources

Olympia, Washington 98504

WYOMING

State Engineer's Office

State office Building

Cheyenne, Wyoming 82001 
APPENDIX 3. STATE REGULATIONS APPLICABLE TO GEOTHERMAL RESOURCE DEVELOPMENT PROJECTS

\begin{tabular}{|c|c|c|c|c|}
\hline State & $\begin{array}{l}\text { Legislation Rules } \\
\text { and Regulations }\end{array}$ & $\begin{array}{c}\text { Administrative/Regulatory } \\
\text { Agency and Other } \\
\text { Agencies Responsible }\end{array}$ & $\begin{array}{c}\text { Fnvironmental Protection } \\
\text { Requirements }\end{array}$ & Additional Comments \\
\hline Alaska & $\begin{array}{l}\text { 1. Geothermal Resources Leas } \\
\text { Ing Act of } 1971 \text {, State Law } \\
38.05 .181 \text { (1971). } \\
\text { 2. Leasing Regulations - 11AAC } \\
84.700 \text { to } 84.720(1974) \text {. } \\
\text { 3. Drilling Regulations - } \\
\text { 11AAC } 94.730(1974)\end{array}$ & $\begin{array}{l}\text { 1. Dept. of Natural Resources } \\
\text { 2. Dept. of Environmental } \\
\text { Conservation (may be re- } \\
\text { quested to assist DNR In } \\
\text { taking those measures } \\
\text { necessary to protect } \\
\text { natural resources and pre- } \\
\text { vent pollution of the } \\
\text { state's waters). }\end{array}$ & $\begin{array}{l}\text { The commissioner of the Dept. } \\
\text { of Natural Resources has } \\
\text { authority to require tests or } \\
\text { work of the owner of a geother- } \\
\text { mal well in order to prevent } \\
\text { poliution of the state's water- } \\
\text { shed and to protect the natural } \\
\text { resources. }\end{array}$ & , \\
\hline Arizona & $\begin{array}{l}\text { 1. Arizona Geothermal Resources } \\
\text { Statute, Article } 4 \text { Sections } \\
27-651 \text { to 27-666 (1972) } \\
\text { 2. Leasing Regulations - Land } \\
\text { Dept. Regulations, Ch. 5, } \\
\text { Art. 21 (R12-5-801 to 811). } \\
\text { 3. Drilling Regulations - "Gen- } \\
\text { eral Rules and Regulations } \\
\text { Governing the Conservation } \\
\text { of Geothermal Resources;" } \\
\text { O11 \& Gas Conservation Com- } \\
\text { miss1on (Title 27, Ch. 4, } \\
\text { Art. 21), 1972. }\end{array}$ & $\begin{array}{l}\text { 1. Oil \& Gas Conservation } \\
\text { Commission }\end{array}$ & $\begin{array}{l}\text { Power Plant Transmission Line } \\
\text { S1ting Commission (1971), Arti- } \\
\text { cle } 6.2 \text {, requires "Certificate } \\
\text { of Environmental Compatibility" } \\
\text { as evidence of approval by state } \\
\text { of sites for a plant or trans- } \\
\text { mission line or both. }\end{array}$ & 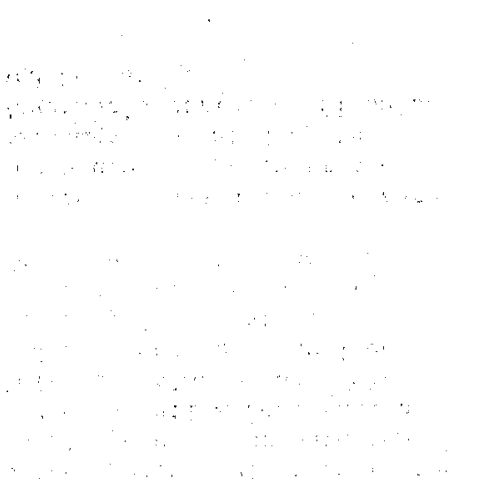 \\
\hline$\because \quad \therefore$ & $\begin{array}{l}\text { 1. California Environmental } \\
\text { Quality Act of } 1970 \text {. } \\
\text { 2. Geothermal Resources Act of } \\
1967, \text { Publfc Resources Code, } \\
\text { Div. } 6, \text { Part } 2 \text {, Ch. 3, Arti- } \\
\text { cle } 5.5 \text { (6902-6925) (Stat- } \\
\text { utes of 1967, Ch. 1398). } \\
\text { 3. Drilling Regulations - Pub- } \\
\text { 1cation No. PRCO2 of the } \\
\text { California Division of O11 } \\
\text { \& Gas - California Laws for } \\
\text { Conservation of Geothermal } \\
\text { Resources. }\end{array}$ & $\begin{array}{l}\text { 1. Dept. of Conservation } \\
\text { - Div. of Oil \& Gas } \\
\text { - Div. of Forestry } \\
\text { 2. Geothermal Resources Board } \\
\text { 3. State Lands Commission } \\
\text { 4. Additional agencies whose } \\
\text { rules and provisions the } \\
\text { user must comply with: } \\
\text { - Dept. of Fish \& Game } \\
\text { - Dept. of Industrial } \\
\text { Safety } \\
\text { - Calif. Public Utilities } \\
\text { Commission }\end{array}$ & $\begin{array}{l}\text { For multiple and phased } \\
\text { projects - where individual } \\
\text { projects are, or a phased } \\
\text { project is to be undertaken } \\
\text { and where the total under- } \\
\text { taking comprises a project } \\
\text { with significant environ- } \\
\text { mental effect, the Div. must } \\
\text { prepare a single EIR for the } \\
\text { ultimate project unless: } \\
\text { a. The project's environ- } \\
\text { mental ef fect will be better } \\
\text { known at the conclusion of a } \\
\text { particular phase, and }\end{array}$ & $\begin{array}{l}\text { Where an individual project } \\
\text { is a necessary precedent for } \\
\text { action on a larger project, or } \\
\text { commits the State Lands Com- } \\
\text { mission to a larger project, } \\
\text { with significant environmental } \\
\text { effect, an EIR must be pre- } \\
\text { pared that addresses the scope } \\
\text { of the larger project. Where } \\
\text { one project is one of several } \\
\text { similar projects of a public } \\
\text { agency, but is not deemed a } \\
\text { part of a larger undertaking } \\
\text { or a larger project, the } \\
\text { agency may prepare one EIR for } \\
\text { all projects, or one for each }\end{array}$ \\
\hline
\end{tabular}


APPENDIX 3. Continued

\begin{tabular}{|c|c|c|c|c|}
\hline State & $\begin{array}{l}\text { Legislation Rules } \\
\text { and Regulations }\end{array}$ & $\begin{array}{c}\text { Adminfstrative/Regulatory } \\
\text { Agency and Other } \\
\text { Agencies Responsible }\end{array}$ & $\begin{array}{l}\text { Environmental Protection } \\
\text { Requirements }\end{array}$ & Additional Comments \\
\hline $\begin{array}{l}\text { California } \\
\text { (cont.) }\end{array}$ & $\begin{array}{l}\text { 4. Leasing Regulations - Public } \\
\text { Resources Code, Div. 6, Part } \\
\text { 2, Ch. 3, Art. 5.5 (Statutes } \\
\text { of 1967, Ch. 1398) also Ch. } \\
4 \text {, Secs. 3714.5, 3723.5, and } \\
3728.5 \text { (1974). } \\
\text { 5. Title 2, California Admin- } \\
\text { 1strative Code, Div. 3. } \\
\text { (Geothermal operations on } \\
\text { state forests). } \\
\text { 6. Title 14, California Admin- } \\
\text { istrative Code, Div. } 2 \text {. } \\
\text { (All regulations for Geo- } \\
\text { thermal Development concern- } \\
\text { ing the Division O1l \& Gas). } \\
\text { 7. Title 14, California Admin- } \\
\text { istrative Code, Div. 6. } \\
\text { (Deals with environmental } \\
\text { quality, the evaluation of } \\
\text { projects, and the preparation } \\
\text { and evaluation of environ- } \\
\text { mental impact reports). }\end{array}$ & $\begin{array}{l}\text { - Solid Waste Management } \\
\text { Board } \\
\text { - State Water Resources } \\
\text { Control Board } \\
\text { - Calif. Energy Resources } \\
\text { Development Commission } \\
\text { - Air Resources Board } \\
\text { - State Board of Equali- } \\
\text { zation }\end{array}$ & $\begin{array}{l}\text { b. The Commission retains a } \\
\text { discretionary approval over } \\
\text { all phases. }\end{array}$ & $\begin{array}{l}\text { project, but should discuss } \\
\text { Impacts on a cumulative basis } \\
\text { in either case. } \\
\text { Where a project with poten- } \\
\text { tially significant effect on } \\
\text { the environment is to be } \\
\text { undertaken by a local agency, } \\
\text { but requires state approval or } \\
\text { financial assistance, the } \\
\text { state agency shall require the } \\
\text { local agency to prepare the } \\
\text { EIR or Negative Declaration. } \\
\text { This must also be done where } \\
\text { federal funds are involved, } \\
\text { but only if a state agency } \\
\text { has discretionary authority } \\
\text { over the use of those funds. } \\
\text { California has a state clear- } \\
\text { ing house for geothermal de- } \\
\text { velopment operated by the } \\
\text { Governor's of fice of Planning } \\
\text { and Research. }\end{array}$ \\
\hline Colorado & $\begin{array}{l}\text { 1. Colorado Geothermal Re- } \\
\text { sources Act of } 1974 \text {, Sec- } \\
\text { tion } 1 \text {, Ch. } 100 \text {, Article } \\
\text { 100, Colorado Revised } \\
\text { Statutes, 1963, as amended. } \\
\text { 2. Regulations under which geo- } \\
\text { thermal operations must abide } \\
\text { by include the following: } \\
\text { 3. Colorado Water Quality Con- } \\
\text { trol Act of 1973, Rules for } \\
\text { Subsurface D1sposal Systems. }\end{array}$ & $\begin{array}{l}\text { 1. Oil \& Gas Conservation } \\
\text { Commission } \\
\text { 2. State Board of Land } \\
\text { Commission } \\
\text { 3. Water Quality Control } \\
\text { Commission } \\
\text { 4. Dept. of Health } \\
\text { 5. Air Pollution Control } \\
\text { Board }\end{array}$ & $\begin{array}{l}\text { A written statement describing } \\
\text { measures that will be taken to } \\
\text { protect against land subsidence, } \\
\text { contamination of surface and } \\
\text { groundwaters and the air, and } \\
\text { excessive noise levels is re- } \\
\text { quired from applicant prior to } \\
\text { issuance of permit. }\end{array}$ & \\
\hline
\end{tabular}


APPENDIX 3. Continued

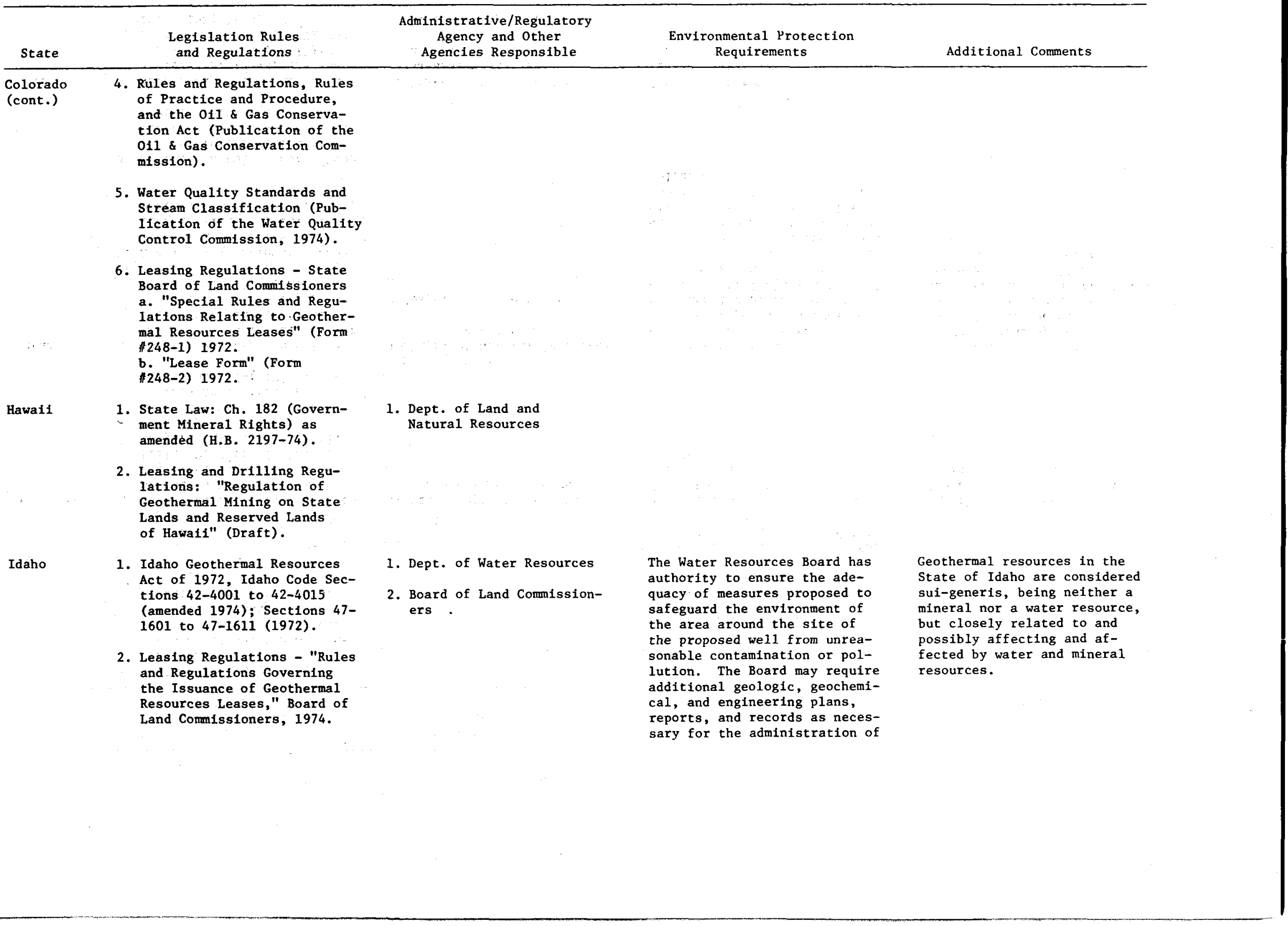




\begin{tabular}{|c|c|c|c|c|}
\hline State & $\begin{array}{l}\text { Legislation Rules } \\
\text { and Regulations }\end{array}$ & $\begin{array}{c}\text { Administrative/Regulatory } \\
\text { Agency and Other } \\
\text { Agencies Responsible }\end{array}$ & $\begin{array}{l}\text { Environmental Protection } \\
\text { Requirements }\end{array}$ & Additional Comments \\
\hline $\begin{array}{l}\text { Idaho } \\
\text { (cont.) }\end{array}$ & $\begin{array}{l}\text { 3. Drilling Regulations - } \\
\text { "Drilling for Geotherma1 } \\
\text { Resources: Rules and Regu- } \\
\text { lations \& Minimum Well Con- } \\
\text { struction Standards," Dept. } \\
\text { of Water Resources, } 1975 \text {. }\end{array}$ & & $\begin{array}{l}\text { the Geothermal Resources Act } \\
\text { of } 1972 \text {. } \\
\text { Permit to Construct required } \\
\text { for new and modified station- } \\
\text { ary sources (site information, } \\
\text { plans, description, specifica- } \\
\text { tions, and drawings should ac- } \\
\text { company the application) - See } \\
\text { Idaho Air Pollution Control Act. }\end{array}$ & \\
\hline Louisiana & $\begin{array}{l}\text { 1. Loulsiana Geothermal and Geo- } \\
\text { pressured Energy Research } \\
\text { and Development Act of } 1975 \text {, } \\
\text { Title } 30 \text {, Part VI, Ch. 7, } \\
\text { Subpart A (Act 735; 1975). }\end{array}$ & $\begin{array}{l}\text { 1. State Dept. of Conservation } \\
\text { - State Mineral Board }\end{array}$ & $\begin{array}{l}\text { An impact statement is required } \\
\text { from the State Mineral Board } \\
\text { before an applicant's geother- } \\
\text { mal lease is processed. }\end{array}$ & $\begin{array}{l}\text { A geothermal lease is subor- } \\
\text { dinate to any ofl, gas, or } \\
\text { mineral lease issued prior to } \\
\text { or following the 1ssuance of a } \\
\text { geothermal lease. }\end{array}$ \\
\hline
\end{tabular}

2. Louislana Geothermal Resources Act, Title 30

Ch. 8 (Act 784; 1975).

Montana

1. State Law: Sections 81-2601 to 81-2613 (Ch. 111, Laws of 1974); Section 60 (amended 1975, S.B. 79); Section 70820 (amended 1975; H.B. 581).

1. Dept. of Natural Resources $\&$ Conservation

2. Dept. of State Lands

2. Leasing Regulations: "Geothermal Rules and Regulations," Title 81, Ch. 6,

Montana Administrative Code, 1975.

3. Drilling Regulations: "Geothermal Investigation Reports," 36-2.8(14), Montana Administrative Code.

Nevada
1. Nevada Water Laws Amendment of 1975, Tftle 48, Sections 2 to 5 (S.B. 158; 1975); Sections 322.030 to 322.060 (S.B. 158; 1975).
A narrative statement is required from the lessee describ ing the proposed measures to be taken for protection of the environment, including the prevention or control of (1) fires,

(2) soil erosion, (3) pollution of the surface and groundwater, (4) damage to fish and wildlife or other natural resources, and (5) air and noise pollution.

1. State Dept. of Conservation: Natural Resources a. Div. of Water Resources

b. State Engineer
The Utility Environmental Protection Act (1971) requires an EIS.
Where there are conflicting leases, including geothermal, coal, mineral and ofl and gas leases, involving the same land, the person who first was issued a lease shall be en-

titled to priority of rights. 
APPENDIX 3. Continued

\begin{tabular}{|c|c|c|c|c|}
\hline State & $\begin{array}{l}\text { Legislation Rules } \\
\text { and Regulations }\end{array}$ & $\begin{array}{l}\text { Administrative/Regulatory } \\
\text { Agency and Other } \\
\text { Agencies Respons } 1 \text { ble }\end{array}$ & $\begin{array}{c}\text { Environmental Protection } \\
\text { Requirements }\end{array}$ & Additional Comments \\
\hline $\begin{array}{l}\text { Nevada } \\
\text { (cont.) }\end{array}$ & $\begin{array}{l}\text { 2. Leasing Regulations: (Leas- } \\
\text { ing moratorium on state } \\
\text { lands since 1967). } \\
\text { 3. Drilling Regulations: (Geo- } \\
\text { thermal regulations pending) } \\
\text { State Water Law and well } \\
\text { drilling regulations. }\end{array}$ & $\begin{array}{l}\text { c. State Land Use Planning } \\
\text { Agency (1973) } \\
\text { a }\end{array}$ & $\therefore$ & - \\
\hline Oregon & 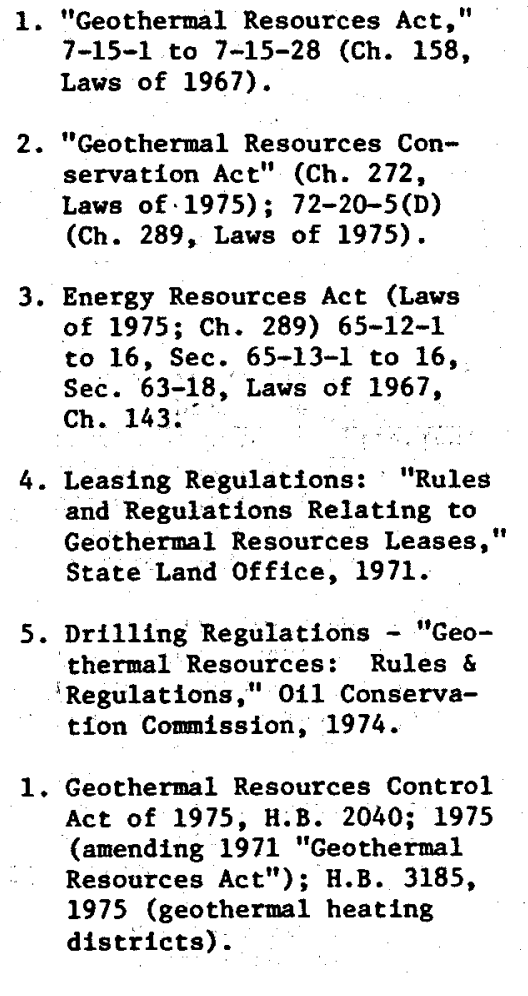 & $\begin{array}{l}\text { 1. Oll Conservation Commission } \\
\text { 2. Public Lands Commission } \\
\text { 3. State Board of Public Health }\end{array}$ & $\begin{array}{l}\text { Environmental impact report (EIR) } \\
\text { required--see Geothermal Leasing } \\
\text { Regulations, Div. of State Lands } \\
\text { (75-010 to } 75-605 \text { ). Rules and } \\
\text { guides for preparing the EIR are } \\
\text { described in the D1v. of State } \\
\text { Lands Rules } 75-625 \text { and } 75-635 \text {. }\end{array}$ & $\begin{array}{l}\text { Persons conducting geothermal } \\
\text { operations on U. S. Government } \\
\text { lands shall also comply with } \\
\text { all applicable state rules and } \\
\text { regulations which are not in } \\
\text { conflict therewith. } \\
\text { Geothermal operations are re- } \\
\text { quired to be conducted in such } \\
\text { a manner as to afford maximum } \\
\text { reasonable profection to the } \\
\text { environment. }\end{array}$ \\
\hline
\end{tabular}


APPENDIX 3. Continued

\begin{tabular}{|c|c|c|c|c|}
\hline State & $\begin{array}{l}\text { Legislation Rules } \\
\text { and Regulations }\end{array}$ & $\begin{array}{c}\text { Administrative/Regulatory } \\
\text { Agency and Other } \\
\text { Agencies Responsible }\end{array}$ & $\begin{array}{c}\text { Environmental Protection } \\
\text { Requirements }\end{array}$ & Additional Comments \\
\hline $\begin{array}{l}\text { Oregon } \\
\text { (cont.) }\end{array}$ & $\begin{array}{l}\text { 2. Administrative Order No. 4, } \\
\text { Blowout Prevention Rules - } \\
\text { Geothermal Prospect Wells } \\
\text { (1976). } \\
\text { 3. Leasing Regulations: "Geo- } \\
\text { thermal Lease Regulations," } \\
75-010 \text { to } 75-605, \text { Div, of } \\
\text { State Lands (revised 1975). } \\
\text { 4. Drilling Regulations: } \\
\text { "Geothermal Regulations," } \\
\text { Ch. 632, Div. } 2 \text { (20-005 } \\
\text { through 20-170), Admin- } \\
\text { Istrative Rules Compilation, } \\
\text { 1972 (Dept. of Geology and } \\
\text { Mineral Industries). }\end{array}$ & $\begin{array}{l}\text { 4. State Fish \& Wildlife } \\
\text { Commission } \\
\text { 5. Land Conservation and } \\
\text { Development Commission } \\
\text { 6. Dept. of Energy } \\
\text { 7. Water Resources Board } \\
\text { 8. State Soil \& Water } \\
\text { Conservation } \\
\text { 9. State Parks Superintendent } \\
\text { 10. State Highway Engineer } \\
\text { 11. Nuclear \& Thermal Energy } \\
\text { Council } \\
\text { 12. State Board of Forestry } \\
\text { 13. Oregon Div. of Employment } \\
\text { 14. Div. of Health } \\
\text { 15. Bureau of Labor } \\
\text { 16. Workmen's Compensation } \\
\text { Dept. } \\
\text { 17. Dept. of Revenue } \\
\text { 18. Public Utility Commission }\end{array}$ & $\begin{array}{l}\text { Also see Geothermal Regulations, } \\
\text { Sections } 20-005 \text { through } 20-170 \\
\text { of Ch. } 632 \text { of the Oregon Admint- } \\
\text { strative Rules Compilation for } \\
\text { requirements for environmental } \\
\text { protection of the Dept. of Geol- } \\
\text { ogy and Mineral Industries. } \\
\text { The State Dept. of Environmental } \\
\text { Quality is responsible for con- } \\
\text { trolling solld waste disposal } \\
\text { and discharge of pollutants into } \\
\text { air and public waters by the } \\
\text { issuance of permits. }\end{array}$ & , \\
\hline Texas & $\begin{array}{l}\text { 1. Geothermal Resources Act } \\
\text { of } 1975 \text { (S.B. 685; 1975). } \\
\text { 2. Drilling Regulations: } \\
\text { a. "Rules and Regulations } \\
\text { Governing Drilling and } \\
\text { Producing on Permanent Free } \\
\text { School Lands," School Land } \\
\text { Board, 1974. }\end{array}$ & $\begin{array}{l}\text { 1. Railroad Commission of Texas } \\
\text { 2. Texas Water Quality Board } \\
\text { (involved in saltwater dis- } \\
\text { posal-wel1 applications) }\end{array}$ & $\begin{array}{l}\text { O11 and Gas Docket No. } 20-65 \text {, } \\
518 \text { includes general statements } \\
\text { specifying that the waters of } \\
\text { Texas be protected during any } \\
\text { o11, gas, or geothermal re- } \\
\text { source development operation. }\end{array}$ & \\
\hline
\end{tabular}




\begin{tabular}{|c|c|c|c|c|c|}
\hline State & $\begin{array}{l}\text { Legislation Rules } \\
\text { and Regulations }\end{array}$ & $\begin{array}{c}\text { Administrative/Regulatory } \\
\text { Agency and Other } \\
\text { Agencies Responsible }\end{array}$ & $\begin{array}{c}\text { Environmental Protection } \\
\text { Requirements }\end{array}$ & Additional Comments & 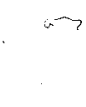 \\
\hline $\begin{array}{l}\text { Texas } \\
\text { (cont.) }\end{array}$ & $\begin{array}{l}\text { b. Railroad Commission of } \\
\text { Texas - Rules Having State- } \\
\text { wide General Application } \\
\text { to 011, Gas, and Geother- } \\
\text { mal Resources Operations } \\
\text { with1n the State of Texas } \\
(051.02 .02 .000 \text { to } \\
051.02 .02 .080) \text {, Texas } \\
\text { Railroad Commission, 011 } \\
\text { \& Gas Div., } 1976 \text {. }\end{array}$ & & Y & 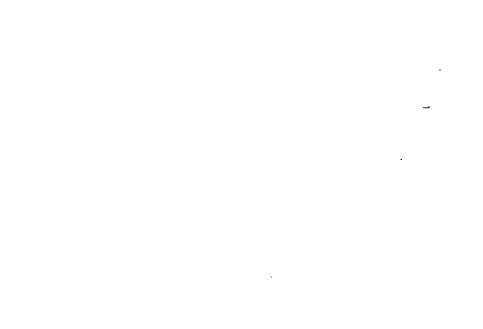 & \\
\hline Utah & $\begin{array}{l}\text { 1. State Law: Sec. 73-1-20, } \\
\text { (Ch. 189; Laws of 1973). } \\
\text { 2. Leasing Regulations - "Rules } \\
\text { and Regulations Governing } \\
\text { the Issuance of Mineral } \\
\text { Leases," State Land Board, } \\
\text { 1973. "Geothermal Steam } \\
\text { Lease and Agreement (1973) } \\
\text { (the lease form contains } \\
\text { the regulations). } \\
\text { 3. Drilling Regulations - } \\
\text { "Rules and Regulations of } \\
\text { the Div. of Water Rights } \\
\text { for Wells Used for the Dis- } \\
\text { covery and Production of } \\
\text { Geothermal Energy in the } \\
\text { State of Utah" (Draft - } \\
\text { 1975). }\end{array}$ & $\begin{array}{l}\text { 1. Div. of Water Rights } \\
\text { 2. State Land Board }\end{array}$ & $\begin{array}{l}\text { The owner of a proposed injec- } \\
\text { tion well shall provide the } \\
\text { Div. of Water Rights with such } \\
\text { information it deems necessary } \\
\text { for the evaluation of the } \\
\text { impact of such injection on } \\
\text { the geothermal reservoir and } \\
\text { other natural resources. }\end{array}$ & $\begin{array}{l}\text { The state lessee has a prior } \\
\text { right to a separate mineral } \\
\text { lease for minerals of possible } \\
\text { recoverable value found in } \\
\text { formations intercepted by } \\
\text { mining or drilling operations } \\
\text { in connection with geothermal } \\
\text { production. }\end{array}$ & \\
\hline Washington & $\begin{array}{l}\text { 1. Geothermal Resources Act of } \\
1974 \text { (Sub. H.B. 135; 1974). } \\
\text { 2. Leasing Regulations - "Geo- } \\
\text { thermal Leasing Policy," } \\
\text { Dept. of State Lands } \\
\text { (Draft, 1975). } \\
\text { 3. Drilling Regulations - } \\
\text { "Geothermal Rules and Regu- } \\
\text { lations," Dept. of Natural } \\
\text { Resources (Draft, 1975). }\end{array}$ & $\begin{array}{l}\text { 1. Div. of Mines and Geol- } \\
\text { ogy of the Dept. of } \\
\text { Natural Resources } \\
\text { 2. Dept. of Ecology }\end{array}$ & $\begin{array}{l}\text { The Dept. of Ecology is the } \\
\text { agency with the responsibility } \\
\text { to manage and develop air and } \\
\text { water resources in an orderly, } \\
\text { efficient and effective manner. } \\
\text { Uses a form of EIS. }\end{array}$ & $\begin{array}{l}\text { Dept. of Natural Resources } \\
\text { has authority to condition } \\
\text { permits to reduce negative } \\
\text { environmental impacts. } \\
\text { The State of Washington has } \\
\text { declared geothermal resources } \\
\text { to be sui-generis. (Refer to } \\
\text { Additional Comments for Idaho, } \\
\text { this Appendix.) }\end{array}$ & \\
\hline
\end{tabular}


APPENDIX 3. Continued

\begin{tabular}{|c|c|c|c|c|}
\hline State & $\begin{array}{l}\text { Legislation Rules } \\
\text { and Regulations }\end{array}$ & $\begin{array}{c}\text { Administrative/Regulatory } \\
\text { Agency and Other } \\
\text { Agencies Responsible }\end{array}$ & $\begin{array}{c}\text { Environmental Protection } \\
\text { Requirements }\end{array}$ & Additional Comments \\
\hline Wyoming & $\begin{array}{l}\text { 1. State Law: Title } 41 \text {, Ch. } 2 \text {, } \\
\text { Art. } 9-\text { "Underground } \\
\text { Water" - Sec. } 41-121 \text { amended } \\
\text { in } 1973 \text { to Include "hot } \\
\text { water and geothermal steam" } \\
\text { as underground waters. } \\
\text { 2. Leasing Regulations: "Rules } \\
\text { and Regulations Governing } \\
\text { the Issuance of Geothermal } \\
\text { Resource Permits and Leases," } \\
\text { State Board of Land Commis- } \\
\text { sioners, 1975. } \\
\text { 3. Drilling Regulations: } \\
\text { (pending) Oil and Gas Con- } \\
\text { servation Commission. }\end{array}$ & $\begin{array}{l}\text { 1. State Board of Land Commis- } \\
\text { sioners } \\
\text { 2. Dept. of Environmental } \\
\text { Quality (Water Control } \\
\text { Board) } \\
\text { 3. Dept. of Game \& Fish }\end{array}$ & $\begin{array}{l}\text { Permit applications must in- } \\
\text { clude a statement describing } \\
\text { the quality and proposed use } \\
\text { of underlying groundwaters and } \\
\text { adjacent surface waters, and a } \\
\text { statement of proposed liquid, } \\
\text { solid, or gaseous waste dis- } \\
\text { posal methods necessary for the } \\
\text { protection and preservation of } \\
\text { existing land and water uses. }\end{array}$ & : \\
\hline
\end{tabular}



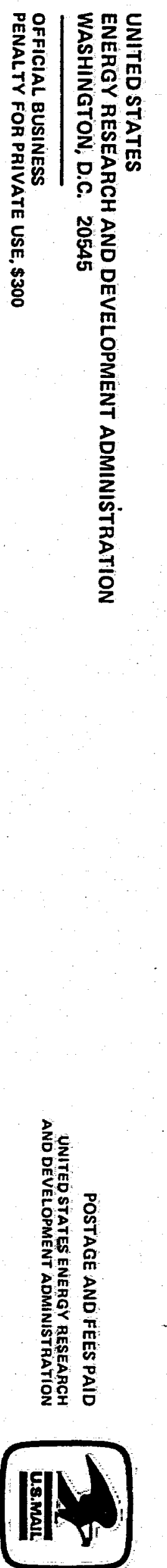